Prepared in cooperation with the U.S. Fish and Wildlife Service

Optimization of Salt Marsh Management at the Long Island National Wildlife Refuge Complex, New York, Through Use of Structured Decision Making

Open-File Report 2021-1070

Version 1.1, August 2021 
Cover. Photograph of salt marsh habitat at Wertheim National Wildlife Refuge, Brookhaven, New York; photograph by U.S. Fish and Wildlife Service. 


\section{Optimization of Salt Marsh Management at the Long Island National Wildlife Refuge Complex, New York, Through Use of Structured Decision Making}

By Hilary A. Neckles, James E. Lyons, Jessica L. Nagel, Susan C. Adamowicz, Toni Mikula, and Monica R. Williams

Prepared in cooperation with the U.S. Fish and Wildlife Service

Open-File Report 2021-1070

Version 1.1, August 2021 


\section{U.S. Geological Survey, Reston, Virginia: 2021 \\ First release: 2021 \\ Revised: August 2021 (ver 1.1)}

For more information on the USGS - the Federal source for science about the Earth, its natural and living resources, natural hazards, and the environment—visit https://www.usgs.gov or call 1-888-ASK-USGS.

For an overview of USGS information products, including maps, imagery, and publications, visit https://store.usgs.gov/.

Any use of trade, firm, or product names is for descriptive purposes only and does not imply endorsement by the U.S. Government.

The findings and conclusions in this report are those of the authors and do not necessarily represent the views of the U.S. Fish and Wildlife Service.

Although this information product, for the most part, is in the public domain, it also may contain copyrighted materials as noted in the text. Permission to reproduce copyrighted items must be secured from the copyright owner.

Suggested citation:

Neckles, H.A., Lyons, J.E., Nagel, J.L., Adamowicz, S.C., Mikula, T., and Williams, M.R., 2021, Optimization of salt marsh management at the Long Island National Wildlife Refuge Complex, New York, through use of structured decision making (ver. 1.1, August 2021): U.S. Geological Survey Open-File Report 2021-1070, 34 p.,

https://doi.org/10.3133/ofr20211070.

ISSN 2331-1258 (online) 


\section{Acknowledgments}

Pam Denmon and Robert Leffel of the U.S. Fish and Wildife Service (FWS) provided exceptional hospitality at the Eastern Shore of Virginia National Wildlife Refuge, Cape Charles, Virginia, for the 2018 structured decision-making workshop, which included participants from two additional national wildlife refuge administrative units. Nathan Bush of the FWS generated the mapping data used in this report, and Jackie Olson of the U.S. Geological Survey expertly prepared the maps. Technical reviews by Rachel Katz of the FWS and Bill Thompson of the National Park Service greatly improved the quality of this report. 



\section{Contents}

Acknowledgments ……...................................................................................................................

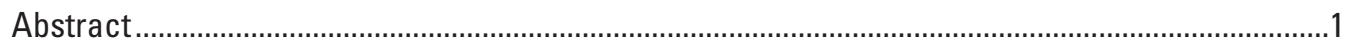

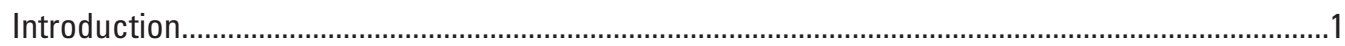

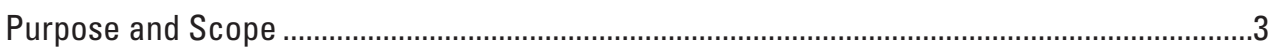

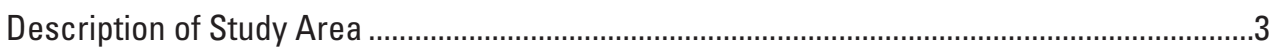

Regional Structured Decision-Making Framework ……..........................................................

Application to the Long Island National Wildlife Refuge Complex.................................................

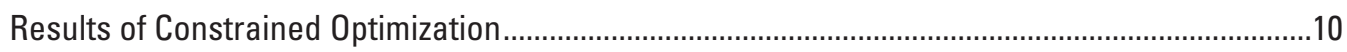

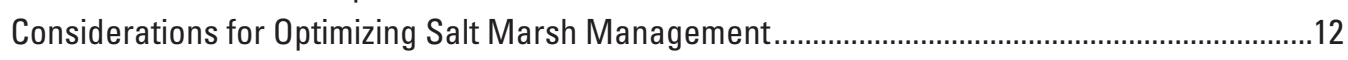

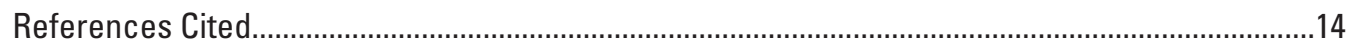

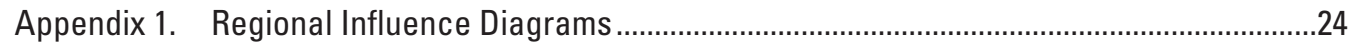

Appendix 2. Utility Functions for the Long Island National Wildlife Refuge Complex ..................31

\section{Figures}

1. Map showing national wildlife refuges and national wildlife refuge complexes of the U.S. Fish and Wildlife Service where salt marsh integrity was assessed

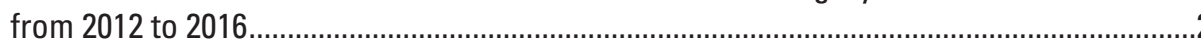

2. Map showing salt marsh management units within three parcels at the Long Island National Wildlife Complex, New York.

3. Graph of predicted total management benefit of various portfolios, expressed as weighted utilities, relative to total cost, at the Long Island National Wildlife Refuge Complex in New York.

4. Bar chart of predicted management benefit of portfolio 6 in comparison to the management benefit from the baseline "no-action" portfolio at the Long Island National Wildlife Refuge Complex in New York...

\section{Tables}

1. Objectives hierarchy for salt marsh management decision problems.

2. Participants in the workshop convened at the Eastern Shore of Virginia National Wildlife Refuge to apply a regional framework for optimizing salt marsh management decisions to three national wildlife refuge administrative units in February 2018

3. Possible management actions for achieving objectives within marsh management units at the Long Island National Wildlife Refuge Complex, New York, estimated costs over 5 years, and predicted outcomes expressed relative to performance metrics

4. Normalized predicted outcomes and estimated total management benefits of possible management actions within 5 marsh management units at the Long Island National Wildlife Refuge Complex, New York...

5. Actions included in various management portfolios to maximize the total management benefits subject to increasing cost constraints at the Long Island National Wildlife Refuge Complex, New York 


\section{Conversion Factors}

International System of Units to U.S. customary units

\begin{tabular}{llll}
\hline & Multiply & \multicolumn{1}{c}{ By } & To obtain \\
\hline meter $(\mathrm{m})$ & 3.281 & foot $(\mathrm{ft})$ & \\
kilometer $(\mathrm{km})$ & 0.6214 & mile $(\mathrm{mi})$ & \\
square meter $\left(\mathrm{m}^{2}\right)$ & 0.0002471 & acre & \\
hectare (ha) & 2.471 & acre & \\
\hline
\end{tabular}

\section{Datum}

Vertical coordinate information is referenced to the North American Vertical Datum of 1988 (NAVD 88).

Horizontal coordinate information is referenced to the North American Datum of 1983 (NAD 83).

Elevation, as used in this report, refers to distance above the vertical datum.

\section{Abbreviations}

FWS U.S. Fish and Wildlife Service

NWR national wildlife refuge

NWRS National Wildlife Refuge System

ppt parts per thousand

USGS U.S. Geological Survey 


\title{
Optimization of Salt Marsh Management at the Long Island National Wildlife Refuge Complex, New York, Through Use of Structured Decision Making
}

\author{
By Hilary A. Neckles, ${ }^{1}$ James E. Lyons, ${ }^{1}$ Jessica L. Nagel, ${ }^{1}$ Susan C. Adamowicz, ${ }^{2}$ Toni Mikula, ${ }^{2}$ and Monica R. \\ Williams $^{2}$
}

\section{Abstract}

Structured decision making is a systematic, transparent process for improving the quality of complex decisions by identifying measurable management objectives and feasible management actions; predicting the potential consequences of management actions relative to the stated objectives; and selecting a course of action that maximizes the total benefit achieved and balances tradeoffs among objectives. The U.S. Geological Survey, in cooperation with the U.S. Fish and Wildlife Service, applied an existing, regional framework for structured decision making to develop a prototype tool for optimizing tidal marsh management decisions at the Long Island National Wildlife Refuge Complex in New York. Refuge biologists, refuge managers, and research scientists identified multiple potential management actions to improve the ecological integrity of five marsh management units within the refuge complex and estimated the outcomes of each action in terms of performance metrics associated with each management objective. Value functions previously developed at the regional level were used to transform metric scores to a common utility scale, and utilities were summed to produce a single score representing the total management benefit that could be accrued from each potential management action. Constrained optimization was used to identify the set of management actions, one per marsh management unit, that could maximize total management benefits at different cost constraints at the refuge-complex scale. Results indicated that, for the objectives and actions considered here, total management benefits may increase consistently up to about $\$ 24,000$, but that further expenditures may yield diminishing return on investment. Potential management actions in optimal portfolios at total costs less than $\$ 24,000$ consistently included approaches for increasing drainage from the marsh surface within the marsh management units. The potential management benefits were derived from expected improvements in surface-water drainage and capacity for marsh elevation

${ }^{1}$ U.S. Geological Survey.

${ }^{2}$ U.S. Fish and Wildlife Service. to keep pace with sea-level rise, and presumed increases in numbers of spiders (as an indicator of trophic health) and tidal marsh obligate birds. The prototype presented here does not resolve management decisions; rather, it provides a framework for decision making at the Long Island National Wildlife Refuge Complex that can be updated as new data and information become available. Insights from this process may also be useful to inform future habitat management planning at the refuges.

\section{Introduction}

The National Wildlife Refuge System (NWRS) protects extensive salt marsh acreage in the northeastern United States. Much of this habitat has been degraded by a succession of human activities since the time of European settlement (Gedan and others, 2009), and accelerated rates of sea-level rise exacerbate these effects (Gedan and others, 2011; Kirwan and Megonigal, 2013). Therefore, strategies to restore and enhance the ecological integrity of national wildlife refuge (NWR) salt marshes are regularly considered. Management may include such activities as reestablishing natural hydrology, augmenting or excavating sediments to restore marsh elevation, controlling invasive species, planting native vegetation, minimizing shoreline erosion, and remediating contaminant problems. Uncertainty stemming from incomplete knowledge of system status and imperfect understanding of ecosystem dynamics commonly hinders management predictions and consequent selection of the most effective management options. Consequently, tools for identifying appropriate assessment variables and evaluating tradeoffs among management objectives are valuable to inform marsh management decisions.

Structured decision making is a systematic approach to improving the quality of complex decisions that integrates assessment metrics into the decision process (Gregory and Keeney, 2002). This approach involves identifying measurable management objectives and potential management actions, predicting management outcomes, and evaluating tradeoffs to choose a preferred alternative. From 2008 to 2012, the 
U.S. Geological Survey (USGS) and U.S. Fish and Wildlife Service (FWS) used structured decision making to develop a framework for optimizing management decisions for NWR salt marshes in the FWS Northeast Region (that is, salt marshes in the coastal region from Maine through Virginia). The structured decision-making steps were applied through successive "rapid prototyping" workshops, an iterative process in which relatively short periods of time are invested to continually improve the decision structure (Blomquist and others, 2010; Garrard and others, 2017). The decision framework includes regional management objectives addressing critical components of salt marsh ecosystems, and associated performance metrics for determining whether objectives are achieved (Neckles and others, 2015). The regional objectives structure served as the foundation for a consistent protocol for monitoring salt marsh integrity at these northeastern coastal refuges, in which the monitoring variables are linked explicitly to management goals (Neckles and others, 2013). From 2012 to 2016, this protocol was used to conduct a baseline assessment of salt marsh integrity at all 17 refuges or refuge complexes in the FWS Northeast Region with salt marsh habitat (fig. 1).

The Long Island National Wildlife Refuge Complex consists of 10 parcels on Long Island, New York. Three of the parcels (Lido Beach Wildlife Management Area, Seatuck National Wildlife Refuge, and Wertheim National Wildlife Refuge) collectively protect about 193 hectares of salt marsh along the south shore of Long Island (fig. 2). These marsh areas provide critical nesting and wintering habitat for bird species of highest conservation priority, including

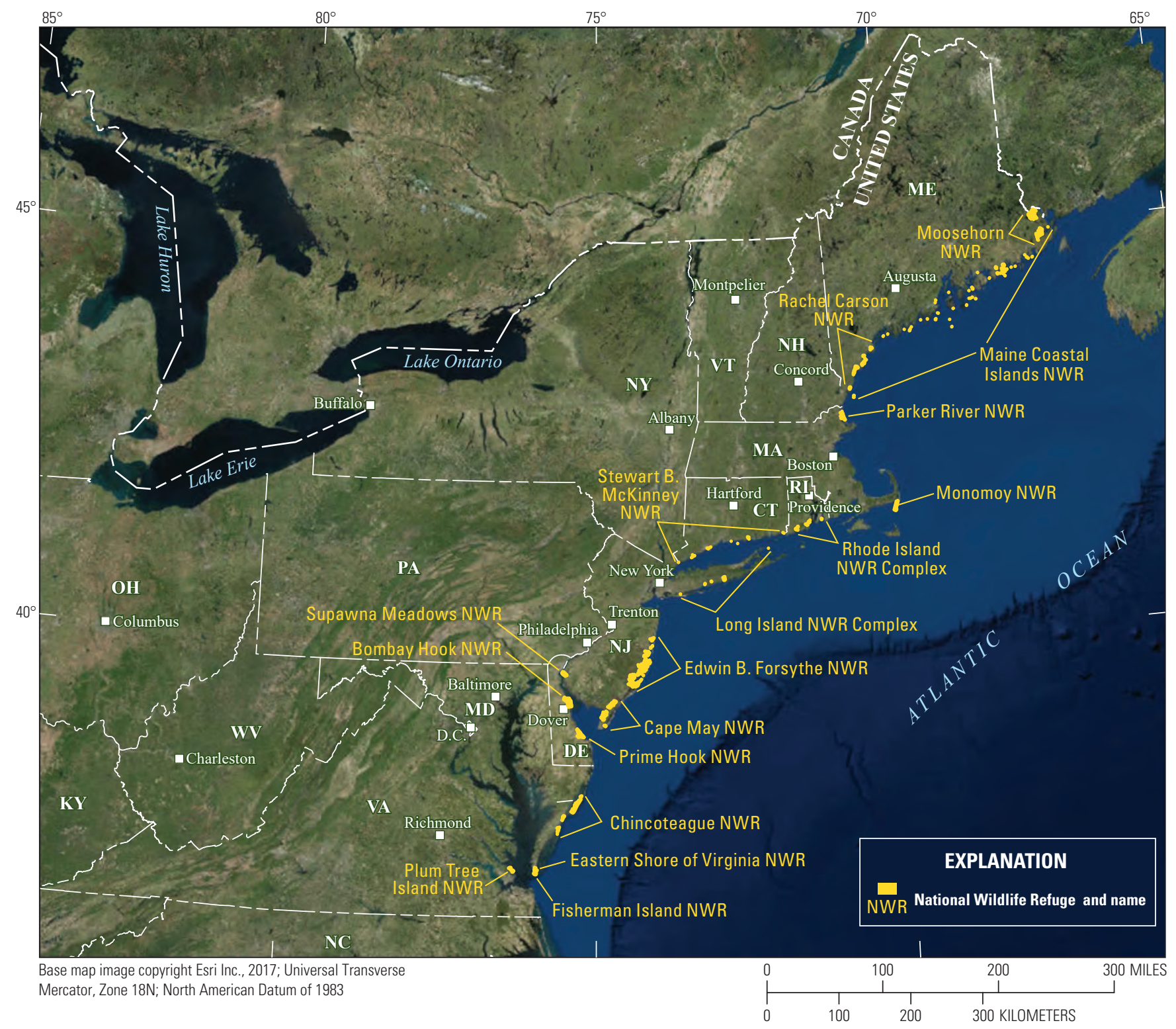

Figure 1. Map showing national wild life refuges and national wildlife refuge complexes of the U.S. Fish and Wildlife Service where salt marsh integrity was assessed from 2012 to 2016 using the regional monitoring protocol. 
Ammodramus caudacutus (saltmarsh sparrow), Branta bernicla (Atlantic brant), and Anas rubripes (American black duck), in the New England and mid-Atlantic coast bird conservation region of the U.S. North American Bird Conservation Initiative (FWS, 2006; Steinkamp, 2008; U.S. North American Bird Conservation Initiative, 2020). The salt marsh also provides important foraging habitat for wading bird species, such as Ardea alba (great egret), Egretta thula (snowy egret), Ardea herodias (great blue heron), and Plegadis falcinellus (glossy ibis), during breeding and migratory seasons (FWS, 2006; National Audubon Society, 2020). The primary concerns for salt-marsh integrity at this refuge complex are marsh degradation associated with historic hydrologic alterations, spread of the invasive reed Phragmites australis (hereafter referred to as Phragmites), and marsh submergence associated with rising sea level (FWS, 2006; Rochlin and others, 2012; New York State Energy Research and Development Authority, 2017). Salt-marsh management goals set by the FWS for the refuge complex focus on maintaining, restoring, and enhancing high quality habitat for breeding, migrating, and wintering birds. In this study, the regional structured decision-making framework was used to help prioritize management options within the three specified parcels at the refuge complex.

\section{Purpose and Scope}

This report describes the application of the regional structured decision-making framework (Neckles and others, 2015 ) to the Long Island National Wildlife Refuge Complex. The regional framework was parameterized to local conditions through rapid prototyping, producing a decision model for the refuge complex that can be updated as new information becomes available. Included are a suite of potential management actions to achieve objectives in five marsh management units at the refuge complex (fig. 2), approximate costs for implementing each potential action, predictions for the outcome of each management action relative to individual management objectives, and results of constrained optimization to maximize management benefits subject to cost constraints. This decision structure can be used to understand how specific actions may contribute to achieving management objectives and identify an optimum combination of actions, or "management portfolio," to maximize management benefits at the refuge scale for a range of potential budgets. The prototype presented here provides a framework for continually improving the quality of complex management decisions at the Long Island National Wildlife Refuge Complex.

\section{Description of Study Area}

The Long Island National Wildlife Refuge Complex comprises 10 separate parcels across Long Island, New York. Three of the parcels, the Lido Beach Wildlife Management Area in Lido Beach, Seatuck National Wildlife Refuge in Islip, and Wertheim National Wildlife Refuge in Brookhaven, protect oases of salt marsh habitat along this highly developed shoreline. The salt marsh habitat within these three parcels is divided into one marsh management unit at the Lido Beach Wildlife Management Area (fig. 2A); one marsh management unit at the Seatuck National Wildlife Refuge (fig. 2B); and three marsh management units at the Wertheim National Wildlife Refuge (Western Unit, Eastern Unit, and Northern Unit; fig. 2C). Most of the land within 1 kilometer of the marsh management units at Lido Beach Wildlife Management Area and Seatuck National Wildlife Refuge consists of residential and commercial development, whereas most of the land within 1 kilometer of the units at Wertheim National Wildlife Refuge is categorized under natural land uses (land classified by the 2011 National Land Cover Database as categories other than agricultural or developed; Multi-Resolution Land Characteristics Consortium, 2020). All marsh management units contain extensive grid ditching from historic mosquito-control measures. Invasive plants occur in all marsh management units, and reducing the extent of Phragmites is a management goal for the complex (FWS, 2006). Average summer surface-water salinities in the marsh management units were about 28 parts per thousand (ppt) at the Lido Beach Wildlife Management Area (measured in 2014), $27 \mathrm{ppt}$ at the Seatuck National Wildlife Refuge (measured in 2013), and 11-14 ppt at the Wertheim National Wildlife Refuge (FWS, 2016). Given these salinities, the surface water in the marsh management units is classified as mesohaline (5-18 ppt) at Wertheim National Wildlife Refuge and polyhaline (18-30 ppt) at Seatuck National Wildlife Refuge and Lido Beach Wildlife Management Area (as defined by Cowardin and others, 1979). 
$\boldsymbol{A}$

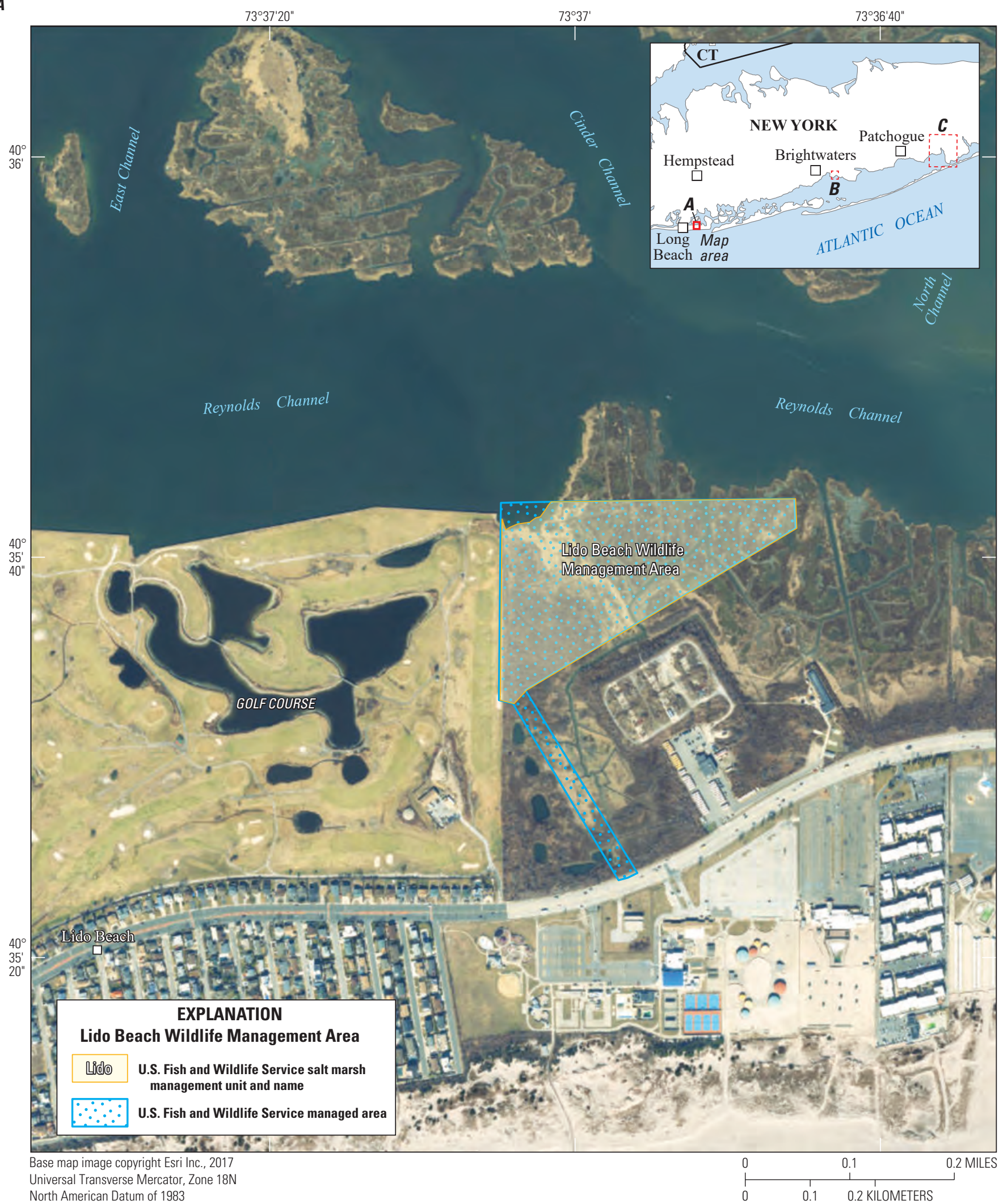

Figure 2. Map showing salt marsh management units within three parcels at the Long Island National Wildlife Complex in New York. $A$, Lido Beach Wildlife Management Area in Lido Beach, New York; $B$, Seatuck National Wildlife Refuge in Islip, New York; and $C$, Wertheim National Wildlife Refuge in Brookhaven, New York. U.S. Fish and Wildlife Service managed areas shown for reference. 


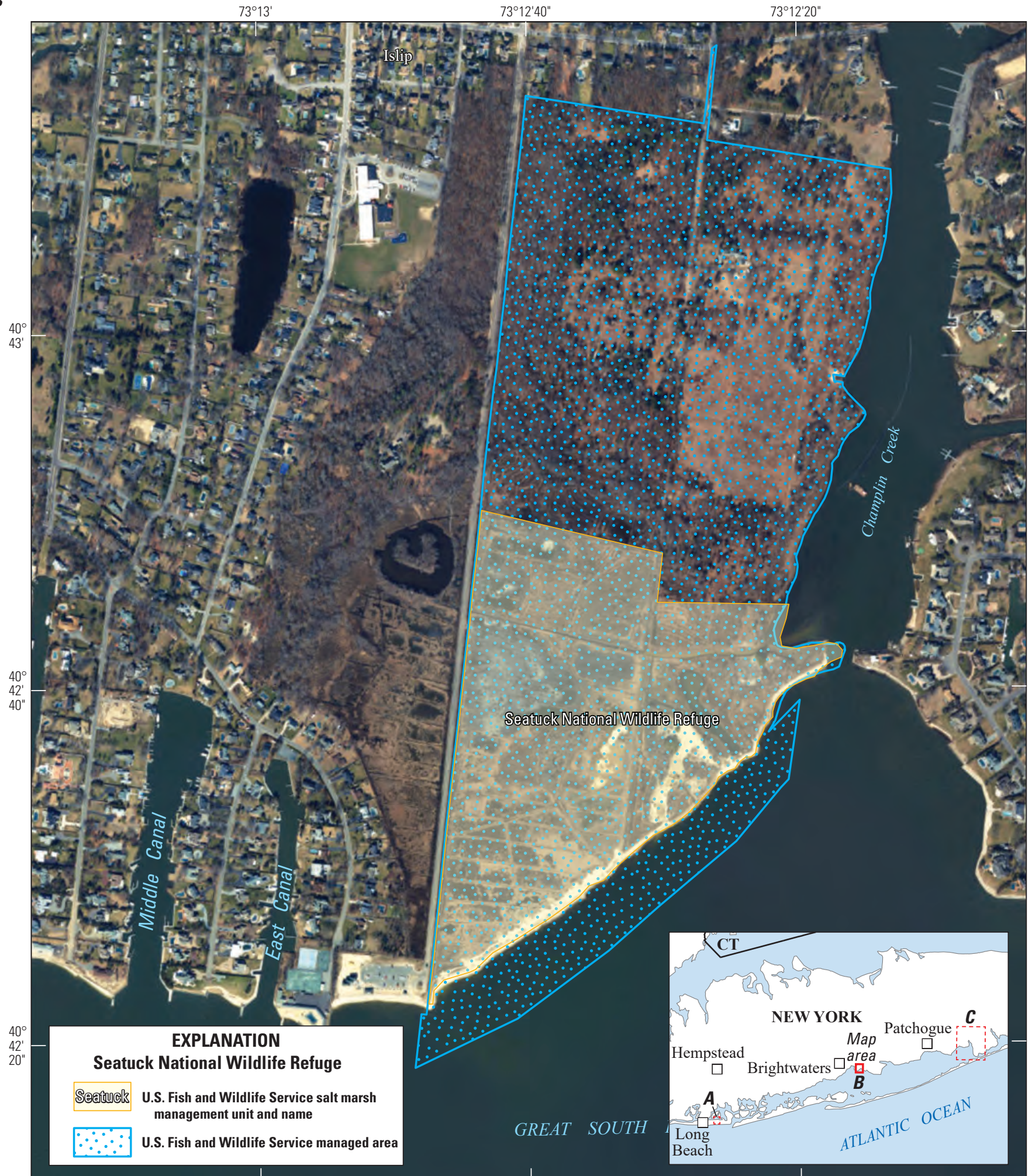

Base map image copyright Esri Inc., 2017

Universal Transverse Mercator, Zone 18N

North American Datum of 1983

0.2

0.3 MILES

Figure 2.-Continued 
C

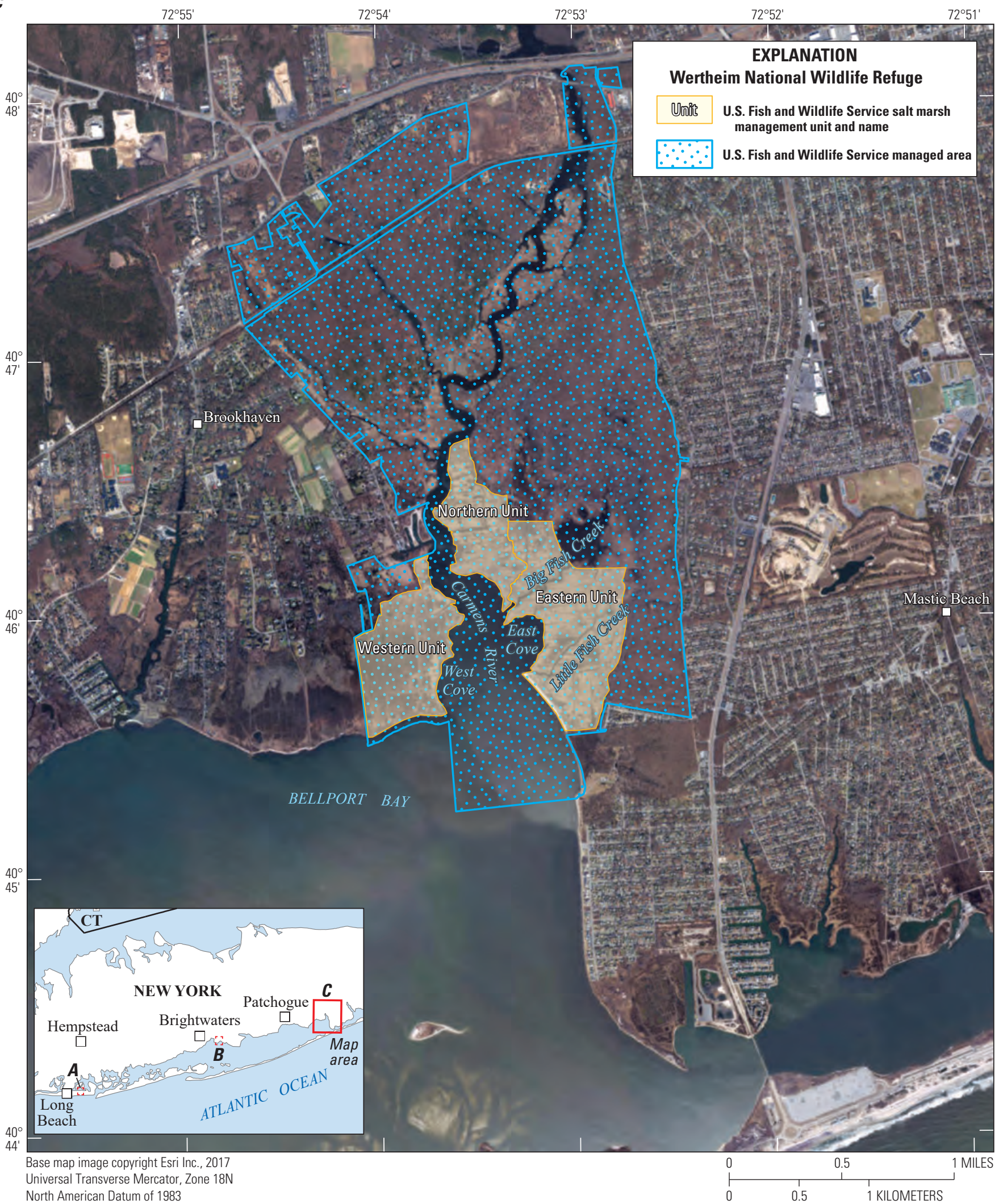

Figure 2.-Continued 


\section{Regional Structured Decision-Making Framework}

A regional framework for assessing and managing salt marsh integrity at northeastern NWRs was developed through collaborative efforts of FWS regional and refuge managers and biologists, salt marsh research scientists, and structured decision-making experts. This process followed the discrete steps outlined by Hammond and others (1999) and Gregory and Keeney (2002):

- 1. Clarify the temporal and spatial scope of the management decision.

-2. Define objectives and performance measures to evaluate whether objectives are achieved.

- 3. Develop alternative management actions for achieving objectives.

- 4. Estimate the consequences or likely outcomes of management actions in terms of the performance measures.

- 5. Evaluate the tradeoffs inherent in potential alternatives and select the optimum alternatives to maximize management benefits.

This sequence of steps was applied through successive workshops to refine the decision structure and incorporate newly available information. Initial development of the structured decision-making framework occurred during a weeklong workshop in 2008 to define the decision problem, specify management objectives, and explore potential strategies available to restore and enhance salt marsh integrity. During 2008 and 2009, workshop results were used to guide field tests of salt marsh monitoring variables (Neckles and others, 2013). Subsequently, in 2012, data and insights gained from these field tests were used in a two-part workshop to refine management objectives and develop the means for evaluating management outcomes (Neckles and others, 2015).

From the outset, FWS goals included development of an approach for consistent assessment of salt marsh integrity across all northeastern NWRs (fig. 1). Within this regional context, staff at a given refuge must periodically determine the best approaches for managing salt marshes to maximize habitat value while considering financial and other constraints. The salt marsh decision problem was thus defined as applying to individual NWRs over a 5-year planning horizon. The objectives for complex decisions can be organized into a hierarchy to help clarify what is most important to decision makers (Gregory and others, 2012). The hierarchy of objectives for salt marsh management decisions (table 1) was based explicitly on the conservation mission of the NWRS, which is upheld through FWS management to "ensure that the biological integrity, diversity, and environmental health of the System are maintained for the benefit of present and future generations of Americans," as mandated in the National Wildlife Refuge System Improvement Act of 1997 (16 U.S.C. §668dd note). Two fundamental objectives, or the overall goals for salt marsh management decisions, were drawn from this policy to maximize (1) biological integrity and diversity, and (2) environmental health, of salt marsh ecosystems. Participants in the prototyping workshops deconstructed these overall goals further into lower level objectives relating to salt marsh structure and function and identified performance metrics to evaluate whether objectives are achieved (table 1). In addition, performance metrics were weighted to reflect the relative importance of each objective (Neckles and others, 2015).

The hierarchy of objectives for salt marsh management (table 1) provides the foundation for identifying possible management actions at individual NWRs and predicting management outcomes. Workshop participants developed preliminary influence diagrams (app. 1), or conceptual models relating management actions to responses by each performance metric (Conroy and Peterson, 2013), to guide this process. To allow metric responses to be aggregated into a single, overall performance score, participants also defined value functions relating salt marsh integrity metric scores to perceived management benefit on a common, unitless "utility" scale (Keeney and Raiffa, 1993). Stakeholder elicitation was used to determine the form of each value function relating the original metric scale to the utility scale, ranging from 0 , representing the lowest management benefit, to 1 , representing the highest benefit (app. 2). Neckles and others (2015) provided details regarding development of the structured decision-making framework and a case-study application to Prime Hook National Wildlife Refuge in Delaware. 
Table 1. Objectives hierarchy for salt marsh management decision problems.

[Two fundamental objectives (overall goals of the decision problem) draw directly from U.S. Fish and Wildlife Service (FWS) National Wildlife Refuge System policy to maintain, restore, and enhance biological integrity, diversity, and environmental health within the refuge complex. These are broken down into lower level objectives focused on specific aspects of marsh structure and function. Values in parentheses are weights assigned to objectives, reflecting their relative importance. Weights on any branch of the hierarchy (that is, objectives that are at the same level of the hierarchy under a fundamental objective) sum to one. The weight for each metric is the product of the weights from each level of the hierarchy leading to that metric. See also Neckles and others (2015). NA, not applicable]

\begin{tabular}{|c|c|c|}
\hline FWS Objectives & Performance metrics & Unit of measurement \\
\hline \multicolumn{3}{|c|}{ Maximize biological integrity and diversity ${ }^{1}(0.5)$} \\
\hline Maximize cover of native vegetation $(0.24)$ & Cover of native vegetation & Percent \\
\hline Maximize nekton abundance $(0.50)$ & Native nekton density & Number per square meter \\
\hline $\begin{array}{l}\text { Maximize use by nonbreeding wetland birds } \\
(0.20)\end{array}$ & $\begin{array}{l}\text { Abundance of American black duck as indicator } \\
\text { species }\end{array}$ & $\begin{array}{l}\text { Relative abundance for refuge during } \\
\text { wintering waterfowl season (low, } \\
\text { medium, high) }\end{array}$ \\
\hline \multicolumn{3}{|c|}{ Maximize environmental health ${ }^{1}(0.5)$} \\
\hline Maintain natural flooding regime $(0.50)$ & $\begin{array}{l}\text { Percent of time marsh surface is flooded relative } \\
\text { to ideal reference system }\end{array}$ & $\begin{array}{l}\text { Absolute deviation from reference in } \\
\text { percentage points }\end{array}$ \\
\hline Maintain natural salinity $(0.50)$ & $\begin{array}{l}\text { Surface-water salinity relative to ideal reference } \\
\text { system }\end{array}$ & $\begin{array}{l}\text { Absolute deviation from reference in } \\
\text { parts per thousand }\end{array}$ \\
\hline $\begin{array}{l}\text { Maintain the extent of the marsh platform } \\
(0.44)\end{array}$ & $\begin{array}{l}\text { Change in marsh surface elevation relative to } \\
\text { sea-level rise }\end{array}$ & $\begin{aligned} 0= & \text { change in elevation is less than amount } \\
& \text { of sea-level rise; } 1=\text { change in elevation } \\
& \text { greater than or equal to amount of sea- } \\
& \text { level rise }\end{aligned}$ \\
\hline Minimize use of herbicides $(0.12)$ & Rate of application & Pints \\
\hline
\end{tabular}

${ }^{1}$ Fundamental objectives of salt marsh management decisions.

${ }^{2}$ Relative abundance based on local knowledge. 


\section{Application to the Long Island National Wildlife Refuge Complex}

In February 2018, FWS regional biologists, biologists and managers from four northeastern NWR administrative units and USGS research scientists (table 2) participated in a 1.5-day rapid-prototyping workshop to apply the regional structured decision-making framework to the Eastern Shore of Virginia, Fisherman Island, and Plum Tree Island National Wildlife Refuges and the Long Island National Wildlife Refuge Complex. Participants worked within refuge-specific small groups to focus on management issues at individual refuges. Plenary discussions of common patterns of salt marsh degradation, potential management strategies, and mechanisms of ecosystem response offered additional insights to enhance refuge-specific discussions.

Participants identified a range of possible management actions for achieving objectives within each marsh management unit at the Long Island National Wildlife Refuge Complex and estimated the total cost of implementation over a 5-year period; the specific years of implementation were not identified in this prototype. Potential actions to enhance salt marsh integrity included restoring natural marsh hydrology, enhancing avian breeding success, controlling invasive plants, or altering marsh elevation (table 3 , in back of report). Participants predicted the outcomes of each management action 5 years after initial implementation in terms of salt marsh integrity performance metrics. For most metrics, baseline conditions within each unit measured during the 2012-14 salt marsh integrity assessment (FWS, 2016) were used to predict the outcomes of a "no-action" alternative. Baseline conditions were estimated by using expert judgement for three metrics that lacked assessment data (abundance of American black ducks, density of spiders, and change in marsh surface elevation relative to sea-level rise). Regional influence diagrams relating management strategies to outcomes aided in predicting consequences of management actions (app. 1). Although the influence diagrams incorporated the potential effects of stochastic processes, including weather, sea-level rise, herbivory, contaminant inputs, and disease, on management outcomes, no attempt was made to quantify these sources of uncertainty during rapid prototyping. Management predictions also inherently included considerable uncertainty surrounding the complex interactions among controlling factors and salt marsh ecosystem components.

Following the workshop, the potential management benefit of each salt marsh integrity performance metric was calculated by converting salt marsh integrity metric scores (table 3 , workshop output) to weighted utilities (table 4 , in back of report) using regional value functions (app. 2). Weighted utilities were summed across all salt marsh integrity metrics for each action; this overall utility therefore represented the total management benefit, across all objectives, expected to
Table 2. Participants in the workshop convened at the Eastern Shore of Virginia National Wildlife Refuge to apply a regional framework for optimizing salt marsh management decisions to three national wildlife refuge administrative units in February 2018.

[FWS, U.S. Fish and Wildlife Service; NWR, National Wildlife Refuge; USGS, U.S. Geological Survey]

\begin{tabular}{ll}
\hline \multicolumn{1}{c}{ Affiliation } & \multicolumn{1}{c}{ Participant } \\
\hline \multicolumn{1}{c}{ FWS NWR specialists } \\
\hline $\begin{array}{l}\text { Eastern Shore of Virginia and Fisherman } \\
\text { Island NWRs }\end{array}$ & Pam Denmon \\
$\begin{array}{l}\text { Eastern Shore of Virginia and Fisherman } \\
\text { Island NWRs }\end{array}$ & Robert Leffel \\
$\begin{array}{l}\text { Long Island NWR Complex } \\
\text { Plum Tree Island NWR }\end{array}$ & Monica Williams \\
Plum Tree Island NWR & William Crouch \\
\hline \multicolumn{2}{c}{ Research scientists } \\
\hline Rachel Carson NWR & Lauren Cruz \\
\hline \multicolumn{2}{c}{ Susan Adamowicz } \\
\hline USGS Eastern Ecological Science Center & James Lyons \\
USGS Eastern Ecological Science Center & Hilary Neckles \\
\hline
\end{tabular}

accrue from a given management action (table 4). Constrained optimization (Conroy and Peterson, 2013) was used to find the management portfolio (the combination of actions, one action per marsh management unit) that maximizes the total management benefit across all units under varying cost scenarios for the entire refuge complex. Constrained optimization using integer linear programming was implemented in the Solver tool in Microsoft Excel (Kirkwood, 1997).

Budget constraints were increased in $\$ 2,500$ increments up to $\$ 10,000$; in $\$ 10,000$ increments up to $\$ 100,000$; in $\$ 50,000$ increments up to $\$ 300,000$; in $\$ 100,000$ increments up to $\$ 1$ million; and in $\$ 500,000$ increments thereafter. The upper limit to potential costs was not determined in advance; rather, it reflected the total estimated costs of the proposed management actions. A cost-benefit plot of the portfolios identified through the optimization analysis was used to identify the efficient frontier for resource allocation (Keeney and Raiffa, 1993), which is the set of portfolios that are not dominated by other portfolios at similar costs (or the set of portfolios with maximum total benefit for a similar cost). The cost-benefit plot also revealed the cost above which further expenditures would yield diminishing returns on investment. To exemplify use of the decision-making framework to understand how a given portfolio could affect specific management objectives, the refuge-scale management benefits for individual performance metrics were compared between one optimal portfolio and those predicted with no management action taken. 


\section{Results of Constrained Optimization}

Potential management actions identified to improve marsh integrity at the Long Island National Wildlife Refuge Complex included adding sediment to the marsh surface to increase elevation; enhancing marsh drainage through creating runnels or removing ditch plugs; restoring marsh morphology through filling ditches; and controlling invasive plants or predators (table 3 ). For costs ranging from $\$ 0$ to $\$ 625,000$, the estimated management benefits for individual actions across all metrics, measured as weighted utilities, ranged from 0.493 (for implementing invasive plant control in the WertheimNorthern Unit) to 0.973 (for removing ditch plugs and cleaning ditches in the Wertheim-Western Unit), out of a maximum possible total management benefit of 1.0 (table 3 , table 4). In all but one marsh management unit (Lido Beach Wildlife Management Area), the alternative with both the lowest management benefit and lowest cost was applying herbicide to control invasive plants.

Constrained optimization was applied to identify the optimal management portfolios over 5 years for a range of total costs to the refuge complex. As total cost increased from $\$ 0$ (no action in any unit) to about $\$ 302,000$, the total management benefit at the refuge scale increased from 2.735 to 4.609 (a 67-percent increase; table 5) out of a possible maximum of 5.0 (the maximum possible management benefit of 1.0 for any management action, summed across the five marsh management units). Graphical analysis showed a fairly consistent increase in management benefit as costs increased to $\$ 23,900$ (fig. 3, portfolio 6). Portfolio 6 represented the turning point in the cost-benefit analysis; as expenditures increased beyond the cost of portfolio 6 , total management benefit continued to increase but at a lower rate, yielding diminishing returns on investment. There was very little gain in management benefit for expenditures greater than about $\$ 49,000$ (fig. 3, portfolio 8).

Several patterns emerged relative to the potential management actions selected by constrained optimization within the set of portfolios that yielded the greatest total management benefit per unit cost (table 5, portfolios 2 through 6). These portfolios consistently included actions that could improve drainage from the marsh surface. Portfolios up to a total cost of about $\$ 10,000$ included excavating runnels at the Lido
Beach Wildlife Management Area and removing ditch plugs at one or more of the Wertheim National Wildlife Refuge units. As costs increased from $\$ 10,000$ to $\$ 23,900$, portfolios included multiple actions within some of the marsh management units, such as removing ditch plugs and cleaning ditches at Wertheim Northern Unit (portfolio 5) or digging runnels and grading the marsh platform at Seatuck National Wildlife Refuge (portfolio 6). In contrast, some management actions were not included in any portfolio. For example, trapping mesopredators or creating nest mounds were identified to increase sparrow populations at all the marsh management units, but these actions were never selected. Similarly, the management portfolios never included actions that incorporated sediment deposition or invasive plant control.

Examination of the refuge-scale metric responses to actions included in portfolio 6 , which is the turning point in the cost-benefit plot (fig. 3), revealed how implementation could affect specific management objectives. The actions included were predicted to achieve large gains in the overall management benefits derived from increased numbers of tidal marsh obligate birds, increased density of spiders (as an indicator of trophic health), reduced duration of flooding, and the capacity of marsh elevation to keep pace with sea-level rise, and modest gains in the benefits derived from changes in density and species richness of nekton (fig. 4). Ecologically, the combination of actions in portfolio 6 may result in an average 203-percent increase in tidal marsh obligate bird counts (averaged across all marsh management units), 20-percent increase in nekton density, 14-percent increase in nekton species richness, 63-percent decrease in the deviation of surface flooding from the ideal reference condition, and 80-percent increase in spider density (derived as the average difference between the predicted metric scores for the actions implemented in portfolio 6 and the "no-action" alternative; table 3). Implementation of actions in this portfolio was also predicted to improve the capacity for marsh elevation to keep pace with sea-level rise in four of the five marsh management units. The management benefits predicted for portfolios 2 through 5, at total costs up to $\$ 19,300$, were derived primarily from expected improvements in surface-water drainage and capacity for marsh elevation to keep pace with sea-level rise, and presumed increases in densities of spiders and numbers of tidal marsh obligate birds (table 3, table 4). 
Table 5. Actions included in various management portfolios to maximize the total management benefits subject to increasing cost constraints at the Long Island National Wildlife Refuge Complex, New York.

[Letter designations for actions refer to specific actions and are listed in table 3 and table 4. Portfolios represent the combination of potential actions, one per marsh management unit, that maximized the total management benefit across all units, subject to a refuge-wide cost constraint. The management actions constituting individual portfolios were selected using constrained optimization. The total cost represents the sum of costs estimated for each action included in the portfolio. The maximum possible total management benefit for the refuge complex is 5.0, derived as the maximum possible total management benefit of 1.0 for any management action within one management unit, summed across five units. NWR, National Wildlife Refuge; WMA, Wildlife Management Area]

\begin{tabular}{|c|c|c|c|c|c|c|c|}
\hline \multirow[b]{2}{*}{ Portfolio } & \multicolumn{5}{|c|}{ Marsh management unit } & \multirow{2}{*}{$\begin{array}{l}\text { Total cost } \\
\text { (dollars) }\end{array}$} & \multirow{2}{*}{$\begin{array}{c}\text { Total managemen } \\
\text { benefit }\end{array}$} \\
\hline & Seatuck NWR & $\begin{array}{l}\text { Lido Beach } \\
\text { WMA }\end{array}$ & $\begin{array}{c}\text { Wertheim } \\
\text { Western Unit }\end{array}$ & $\begin{array}{l}\text { Wertheim } \\
\text { Eastern Unit }\end{array}$ & $\begin{array}{c}\text { Wertheim } \\
\text { Northern Unit }\end{array}$ & & \\
\hline 1 & A & A & $\mathrm{A}$ & $\mathrm{A}$ & A & 0 & 2.753 \\
\hline 2 & A & B & A & A & $\mathrm{D}$ & 2,375 & 3.294 \\
\hline 3 & A & B & A & $\mathrm{C}$ & $\mathrm{D}$ & 4,875 & 3.603 \\
\hline 4 & A & B & $\mathrm{D}$ & $\mathrm{C}$ & $\mathrm{D}$ & 9,875 & 4.005 \\
\hline 5 & $\mathrm{H}$ & B & $\mathrm{D}$ & $\mathrm{C}$ & M & 19,300 & 4.129 \\
\hline 6 & E & B & $\mathrm{D}$ & $\mathrm{C}$ & $\mathrm{D}$ & 23,900 & 4.263 \\
\hline 7 & $\mathrm{H}$ & $\mathrm{F}$ & $\mathrm{D}$ & $\mathrm{C}$ & $\mathrm{D}$ & 36,800 & 4.308 \\
\hline 8 & E & $\mathrm{F}$ & $\mathrm{D}$ & $\mathrm{C}$ & $\mathrm{D}$ & 48,900 & 4.474 \\
\hline 9 & E & $\mathrm{F}$ & $\mathrm{D}$ & $\mathrm{C}$ & M & 56,400 & 4.506 \\
\hline 10 & E & $\mathrm{F}$ & I & $\mathrm{C}$ & M & 63,150 & 4.509 \\
\hline 11 & E & $\mathrm{F}$ & $\mathrm{O}$ & $\mathrm{C}$ & M & 131,400 & 4.534 \\
\hline 12 & $\mathrm{~F}$ & $\mathrm{~F}$ & I & $\mathrm{C}$ & M & 158,725 & 4.563 \\
\hline 13 & $\mathrm{~F}$ & $\mathrm{~F}$ & $\mathrm{O}$ & $\mathrm{C}$ & $\mathrm{M}$ & 226,975 & 4.588 \\
\hline 14 & $\mathrm{~F}$ & $\mathrm{~F}$ & $\mathrm{O}$ & K & M & 301,975 & 4.609 \\
\hline
\end{tabular}

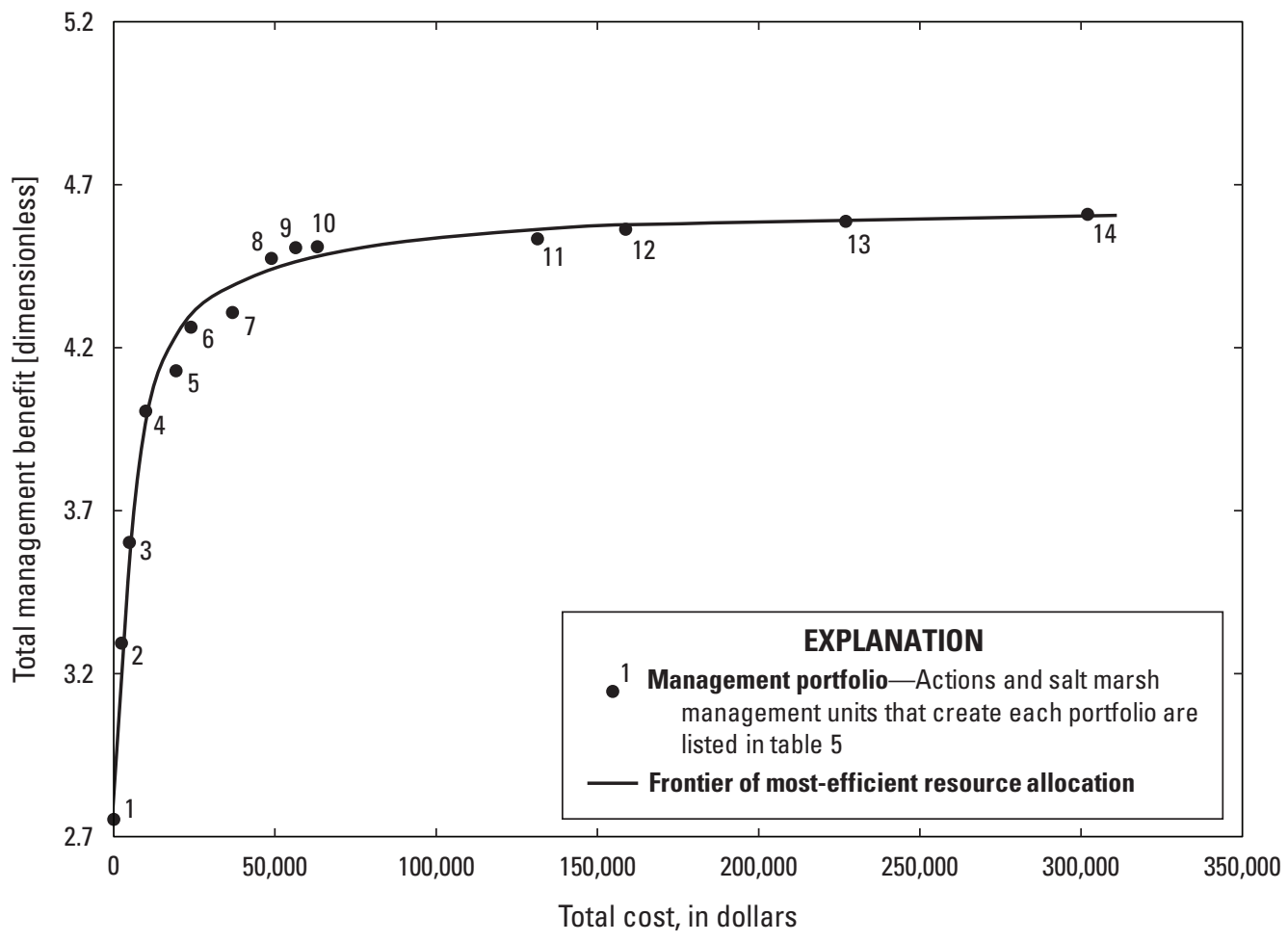

Figure 3. Graph showing predicted total management benefit of various portfolios, expressed as weighted utilities, relative to total cost at the Long Island National Wildlife Refuge Complex in New York. Each portfolio (dot with number) represents a combination of five management actions, one per marsh management unit, as identified in table 5 . The line represents the efficient frontier for resource allocation. 


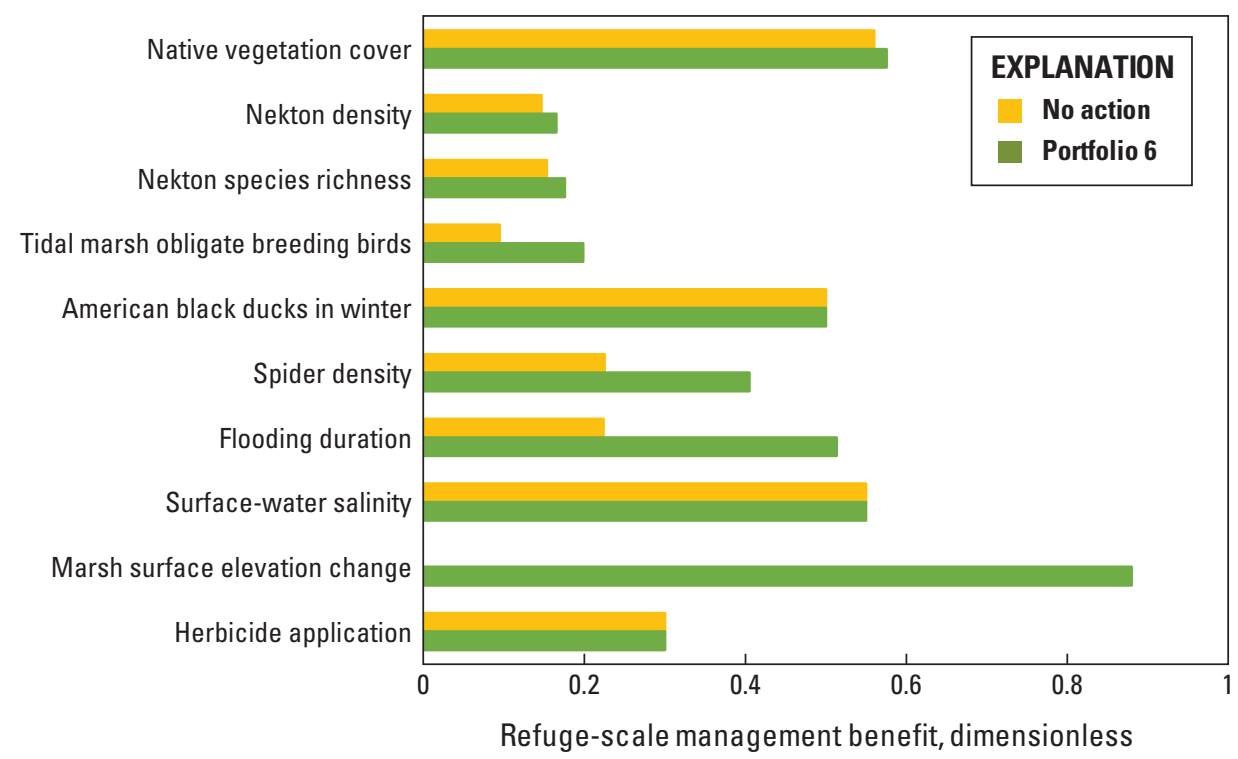

Figure 4. Predicted management benefit at the refuge scale for individual performance metrics, expressed as weighted utilities, resulting from implementation of the management actions included in portfolio 6, in comparison to the management benefit from the baseline "no-action" portfolio, at the Long Island National Wildlife Refuge Complex in New York. Baseline ("no action") predicted management benefit for marsh surface elevation change is 0 . The actions included in each portfolio are listed in table 5.

\section{Considerations for Optimizing Salt Marsh Management}

A regional structured decision-making framework for salt marshes in NWRs in the northeastern United States was applied by the USGS, in cooperation with the FWS, to develop a tool for optimizing management decisions at the Long Island National Wildlife Refuge Complex. Use of the existing regional framework and a rapid-prototyping approach permitted NWR biologists and managers, FWS regional authorities, and research scientists to construct a decision model for the refuge complex within the confines of a 1.5-day workshop. This preliminary prototype provides a local framework for decision making while revealing information needs for future iterations. Insights from this process may also be useful to inform future habitat management planning at the refuge complex.

The suite of potential management actions and predicted outcomes included in this prototype (table 3 ) were based on current understanding of the Long Island National Wildlife Refuge Complex salt marshes and hypothesized processresponse pathways (app. 1). Tidal flooding is the predominant physical control on the structure and function of salt marsh ecosystems (Pennings and Bertness, 2001), and there is widespread scientific effort to elucidate how salt marshes may respond to accelerating rates of sea-level rise and management strategies to enhance their sustainability (Kirwan and Megonigal, 2013; Roman, 2017). Management actions to improve drainage or raise the elevation of the marsh surface are increasingly proposed to reduce vulnerability of northeastern salt marshes threatened with submergence (Wigand and others, 2017). At the Long Island National Wildlife Refuge Complex, various actions were identified to remedy alterations to salt marsh hydrology associated with mosquito control. In particular, ditch plugs were installed in many northeastern marshes to increase surface water habitat for larvivorous fish (Meredith and others, 1985), but this hydrologic manipulation may promote marsh subsidence (Vincent and others, 2013). In this prototype, removing ditch plugs was expected to alleviate the extended water-logging of the marsh substrate that can lead to vegetation loss and subsidence, thereby enhancing marsh capacity to maintain elevation. The predicted high management benefit yielded by ditch plug removal led to its frequent selection within optimal management portfolios. Multiple interacting factors influence the long-term success of restoration actions in prolonging marsh integrity and improving marsh resilience (Roman, 2017). Future iterations of this decision model can incorporate improved understanding of both implementation costs and marsh responses to management actions. In addition, during construction of the regional decision model, a lack of widely available data on rates of vertical marsh growth led to the adoption of a very coarse scale of measurement for change in marsh surface elevation relative to sea-level rise (table 1). From 2008 to 2014, three surface elevation tables (Lynch and others, 2015) were installed in each marsh management unit to obtain high-resolution measurements of change in marsh surface elevation. Incorporating 
this information into subsequent iterations of this structured decision-making framework would likely improve predictions related to the potential for marsh surface elevation to keep pace with sea-level rise.

Results of constrained optimizations (table 5) based on the objectives, management actions, and predicted outcomes included in this prototype identified four areas in which to improve the utility of the prototype for refuge decision making. First, although reducing the extent of Phragmites is a management concern at the Long Island National Wildlife Refuge Complex, application of herbicides as a control measure was not selected for any optimal portfolio. The transparency of the structured decision-making framework reveals the tradeoffs associated with applying herbicide to reduce the spread of invasive plants. In most instances, controlling invasive plants was predicted to increase the percent cover of native vegetation and the abundance of tidal marsh obligate birds (table 3), and increase the management benefits associated with achieving these specific objectives (table 4). However, spraying all but small quantities of herbicides, which are a potential environmental contaminant, also had direct negative consequences on the objective to minimize herbicide use (table 4); whereas applying 35 pints of herbicide per year at the Lido Beach Wildlife Management Area was predicted to increase the total management benefit, applying the quantities of herbicide necessary to control widespread, multiple stands of invasive plants in the other marsh management units was predicted to decrease the total management benefit (table 4). Thus, the benefits associated with use of herbicide to reduce invasive plants may not offset the negative value of environmental contaminants. These results emphasize the importance that refuge managers have placed on controlling spread of Phragmites through various methods, including increasing porewater salinity through tidal restoration (FWS, 2006). This prototype could be adapted to allow managers to evaluate the relative expected benefits and detriments of chemical and other control methods.

Second, controlling predators (Roberts and others, 2017, 2019) and constructing islands as nesting habitat (Benvenuti, 2016) have been proposed for increasing reproductive success of saltmarsh sparrows, but the efficacy of these management actions is unknown. The lack of information to predict management benefits may have contributed to the exclusion of these management actions from optimal portfolios, suggesting that these and other methods to improve nest success might warrant investigation. Future iterations of the decision model might consider additional actions targeting saltmarsh sparrows. For example, recent studies identified acquisition of adjacent parcels for inland marsh-migration (Wiest and others, 2014) and removal of trees or other tall structures near marsh edges to enhance openness (Marshall and others, 2020) as potential approaches for limiting declines of saltmarsh sparrow populations.
Third, partially filling mosquito ditches with plant fiber has shown short-term promise in promoting ditch "self healing" through natural sedimentation and revegetation, but the long-term success of this technique for restoring marsh elevations requires further investigation (Burdick and others, 2020). Although such ditch remediation was identified as a possible mechanism to achieve salt marsh management goals at Wertheim National Wildlife Refuge (table 3), this action was never included in an optimal portfolio. Long-term monitoring of marsh recovery trajectories following experimental ditch remediation will allow refinement of the decision model for Long Island National Wildlife Refuge Complex.

Finally, the constrained optimizations analyzed in this report were based on approximations of management costs. A detailed list of actual expenses can be compiled as salt marsh management is undertaken around the region, including staff time for project planning, as well as materials, equipment, contracts, and staff time for implementation. This will allow future iterations of the decision model to include more accurate cost estimates.

The prototype model for the Long Island National Wildlife Refuge Complex provides a useful tool for decision making that can be updated in the future with new data and information. The spatial and temporal variability inherent in parameter estimates were not quantified during rapid prototyping. Previously, preliminary sensitivity analysis revealed little effect of incorporating ecological variation in abundance of marsh-obligate breeding birds on the optimal solutions for Prime Hook National Wildlife Refuge (Neckles and others, 2015). This lends confidence to use of this framework for decision making; however, including probability distributions for each performance metric in the decision model could be a high priority for future prototypes. Future monitoring of salt marsh integrity performance metrics will be useful to refine baseline parameter estimates and to determine the background rate of change in the absence of management actions; feedback from measured responses to management actions around the region will help reduce uncertainties surrounding management predictions. The structured decision-making framework applied here to the Long Island National Wildlife Refuge Complex is based on a hierarchy of regional objectives and regional value functions relating performance metrics to perceived management benefits. It will be important to ensure that subsequent iterations reflect evolving management objectives and desired outcomes. Elements of the decision model could be further adapted, for example through differential weighting of objectives or altered value functions, to reflect specific, local management goals and mandates. Future optimization analyses that use this framework could also incorporate additional constraints on action selection, such as ensuring that particular actions within individual marsh management units are included in optimal management portfolios, to further tailor the model to refuge-specific needs. 


\section{References Cited}

Benvenuti, B., 2016, Nesting adaptions and conservation of a threatened tidal marsh-nesting bird the salt marsh sparrow: Durham, New Hampshire, University of New Hampshire, Master's thesis, 96 p. [Also available at https://scholar s.unh.edu/thesis/1093/.]

Blomquist, S.M., Johnson, T.D., Smith, D.R., Call, G.P., Miller, B.N., Thurman, W.M., McFadden, J.E., Parkin, M.J., and Boomer, G.S., 2010, Structured decision-making and rapid prototyping to plan a management response to an invasive species: Journal of Fish and Wildlife Management, v. 1, no. 1, p. 19-32. [Also available at https://doi.org/ 10.3996/JFWM-025.]

Burdick, D.M., Moore, G.E., Adamowicz, S.C., Wilson, G.M., and Peter, C.R., 2020, Mitigating the legacy effects of ditching in a New England salt marsh: Estuaries and Coasts, v. 43, no. 7, p. 1672-1679. [Also available at https://doi.org/ 10.1007/s12237-019-00656-5.]

Conroy, M.J., and Peterson, J.T., 2013, Decision making in natural resource management-A structured, adaptive approach: Chichester, United Kingdom, John Wiley and Sons, Ltd., 456 p. [Also available at https://doi.org/10.1002/ 9781118506196.]

Cowardin, L.M., Carter, V., Golet, F.C., and LaRoe, E.T., 1979, Classification of wetlands and deepwater habits of the United States: U.S. Fish and Wildlife Service report FWS/OBS-79/31, 131 p., accessed November 12, 2018, at https://www.fws.gov/wetlands/Documents/Classification-ofWetlands-and-Deepwater-Habitats-of-the-United-States.pdf.

Garrard, G.E., Rumpff, L., Runge, M.C., and Converse, S.J., 2017, Rapid prototyping for decision structuring-An efficient approach to conservation decision analysis, chap. 3 of Bunnefeld, N., Nicholson, E., and Milner-Gulland, E.J., eds., Decision-making in conservation and natural resource management: Cambridge, United Kingdom, Cambridge University Press, p. 46-64. [Also available at https://doi.org/10.1017/9781316135938.003.]

Gedan, K.B., Altieri, A.H., and Bertness, M.D., 2011, Uncertain future of New England salt marshes: Marine Ecology Progress Series, v. 434, p. 229-237. [Also available at https://doi.org/10.3354/meps09084.]

Gedan, K.B., Silliman, B.R., and Bertness, M.D., 2009, Centuries of human-driven change in salt marsh ecosystems: Annual Review of Marine Science, v. 1, no. 1, p. 117-141. [Also available at https://doi.org/10.1146/ annurev.marine.010908.163930.]
Gregory, R., Failing, L., Harstone, M., Long, G., McDaniels, T., and Ohlson, D., 2012, Structured decision making-A practical guide to environmental management choices: Chichester, United Kingdom, John Wiley and Sons, Ltd., 299 p. [Also available at https://doi.org/10.1002/ 9781444398557.]

Gregory, R.S., and Keeney, R.L., 2002, Making smarter environmental management decisions: Journal of the American Water Resources Association, v. 38, no. 6, p. 1601-1612. [Also available at https://doi.org/10.1111/ j.1752-1688.2002.tb04367.x.]

Hammond, J.S., Keeney, R.L., and Raiffa, H., 1999, Smart choices-A practical guide to making better life decisions: Boston, Harvard Business School Press, 242 p.

Keeney, R.L., and Raiffa, H., 1993, Decisions with multiple objectives - Preferences and value tradeoffs: Cambridge, United Kingdom, Cambridge University Press, 569 p. [Also available at https://doi.org/10.1017/CBO9781139174084.]

Kirkwood, C.W., 1997, Strategic decision makingMultiobjective decision analysis with spreadsheets: Belmont, Calif., Duxbury Press, 345 p.

Kirwan, M.L., and Megonigal, J.P., 2013, Tidal wetland stability in the face of human impacts and sea-level rise: Nature, v. 504, no. 7478 , p. 53-60. [Also available at https://doi.org/ 10.1038/nature12856.]

Lynch, J.C., Hensel, P., and Cahoon, D.R., 2015, The surface elevation table and marker horizon technique-A protocol for monitoring wetland elevation dynamics: National Park Service Natural Resource Report NPS/NCBN/NRR 2015/1078, [variously paged], accessed August 24, 2018, at https://irma.nps.gov/DataStore/DownloadFile/531681.

Marshall, H., Blomberg, E.J., Watson, V., Conway, M., Cohen, J.B., Correll, M.D., Elphick, C.S., Hodgman, T.P., Kocek, A.R., Kovach, A.I., Shriver, W.G., Wiest, W.A., and Olsen, B.J., 2020, Habitat openness and edge avoidance predict saltmarsh sparrow abundance better than habitat area: The Condor, v. 122, no. 3, p. 1-13. [Also available at https://doi.org/10.1093/condor/duaa019.]

Meredith, W.E., Saveikis, D.E., and Stachecki, C.J., 1985, Guidelines for "open marsh water management" in Delaware's salt marshes - Objectives, system designs, and installation procedures: Wetlands, v. 5, no. 1, p. 119-133. [Also available at https://doi.org/10.1007/BF03160791.]

Multi-Resolution Land Characteristics Consortium, 2020, NLCD 2011 land cover (CONUS): Multi-Resolution Land Characteristics Consortium database, accessed March 17, 2021, at https://www.mrlc.gov/data. 
National Audubon Society, 2020, Carman's River Estuary: National Audubon Society web page, accessed December 30, 2020, at https://netapp.audubon.org/iba/ Reports/780.

Neckles, H.A., Guntenspergen, G.R., Shriver, W.G., Danz, N.P., Wiest, W.A., Nagel, J.L., and Olker, J.H., 2013, Identification of metrics to monitor salt marsh integrity on national wildlife refuges in relation to conservation and management objectives-Final report-January 2013: U.S. Fish and Wildlife Service, prepared by U.S. Geological Survey, 226 p., accessed May 1, 2018, at https://eco s.fws.gov/ServCat/Reference/Profile/37795.

Neckles, H.A., Lyons, J.E., Guntenspergen, G.R., Shriver, W.G., and Adamowicz, S.C., 2015, Use of structured decision making to identify monitoring variables and management priorities for salt marsh ecosystems: Estuaries and Coasts, v. 38, no. 4, p. 1215-1232. [Also available at https://doi.org/10.1007/s12237-014-9822-5.]

New York State Energy Research and Development Authority, 2017, Integrating SLAMM results and stakeholder priorities to define marsh adaptation strategies: New York State Energy Research and Development Authority Report Number 18-04, prepared by Warren Pinnacle Consulting, Inc., 95 p., 8 app., accessed January 14, 2021, at https:/ /www.nyserda.ny.gov/-/media/Files/Publications/Research/ Environmental/18-04-Integrating-SLAMM-Results-MarshAdaptation-Strategies.pdf.

Pennings, S.C., and Bertness, M.D., 2001, Salt marsh communities, chap. 11 of Bertness, M.D., Gaines, S.D., and Hay, M.E., eds., Marine community ecology: Sunderland, Mass., Sinauer Associates, p. 289-316.

Roberts, S.G., Longenecker, R.A., Etterson, M.A., Ruskin, K.J., Elphick, C.S., Olsen, B.J., and Shriver, W.G., 2017, Factors that influence vital rates of seaside and saltmarsh sparrows in coastal New Jersey, USA: Journal of Field Ornithology, v. 88, no. 2, p. 115-131. [Also available at https://doi.org/10.1111/jofo.12199.]

Roberts, S.G., Longenecker, R.A., Etterson, M.A., Elphick, C.S., Olsen, B.J., and Shriver, W.G., 2019, Preventing local extinctions of tidal marsh endemic seaside sparrows and saltmarsh sparrows in eastern North America: The Condor, v. 121, no. 2, p. 1-14. [Also available at https://doi.org/ 10.1093/condor/duy024.]

Rochlin, I., James-Pirri, M.-J., Adamowicz, S.C., Wolfe, R.J., Capotosto, P., Dempsey, M.E., Iwanejko, T., and Ninivaggi, D.V., 2012, Integrated marsh management (IMM)-A new perspective on mosquito control and best management practices for salt marsh restoration: Wetlands Ecology and Management, v. 20, no. 3, p. 219-232. [Also available at https://doi.org/10.1007/s11273-012-9251-9.].
Roman, C.T., 2017, Salt marsh sustainability-Challenges during an uncertain future: Estuaries and Coasts, v. 40, no. 3, p. 711-716. [Also available at https://doi.org/10.1007/ s12237-016-0149-2.].

Steinkamp, M., 2008. New England/mid-Atlantic coast bird conservation (BCR 30) implementation plan: Atlantic Coast Joint Venture, 251 p., accessed August 15, 2018, at https://www.acjv.org/BCR_30/BCR30_June_23_2008_ final.pdf.

U.S. Fish and Wildlife Service [FWS], 2006, Long Island National Wildlife Refuge Complex-Comprehensive conservation plan: U.S. Fish and Wildlife Service, [variously paged], accessed January 14, 2021, at https://www.fws.gov/ refuge/Wertheim/what_we_do/finalccp.html.

U.S. Fish and Wildlife Service [FWS], 2016, Salt marsh integrity and Hurricane Sandy vegetation, bird and nekton data: U.S. Fish and Wildlife Service database, accessed March 16, 2021, at https://ecos.fws.gov/ServCat/Reference/ Profile/121918.

U.S. North American Bird Conservation Initiative, 2020, Bird conservation regions: U.S. North American Bird Conservation Initiative web page, accessed July 6, 2020, at https:/nabci-us.org/resources/bird-conservation-regions/.

Vincent, R.E., Burdick, D.M., and Dionne, M., 2013, Ditching and ditch-plugging in New England salt marshes-Effects on hydrology, elevation, and soil characteristics: Estuaries and Coasts, v. 36, no. 3, p. 610-625. [Also available at https://doi.org/10.1007/s12237-012-9583-y.].

Wiest, W.A., Shriver, W.G., and Messer, K.D., 2014, Incorporating climate change with conservation planning-A case study for tidal marsh bird conservation in Delaware, USA: Journal of Conservation Planning, v. 10, p. $25-42$.

Wigand, C., Ardito, T., Chaffee, C., Ferguson, W., Paton, S., Raposa, K., Vandemoer, C., and Watson, E., 2017, A climate change adaptation strategy for management of coastal marsh systems: Estuaries and Coasts, v. 40, no. 3, p. 682-693. [Also available at https://doi.org/10.1007/ s12237-015-0003-y.]. 


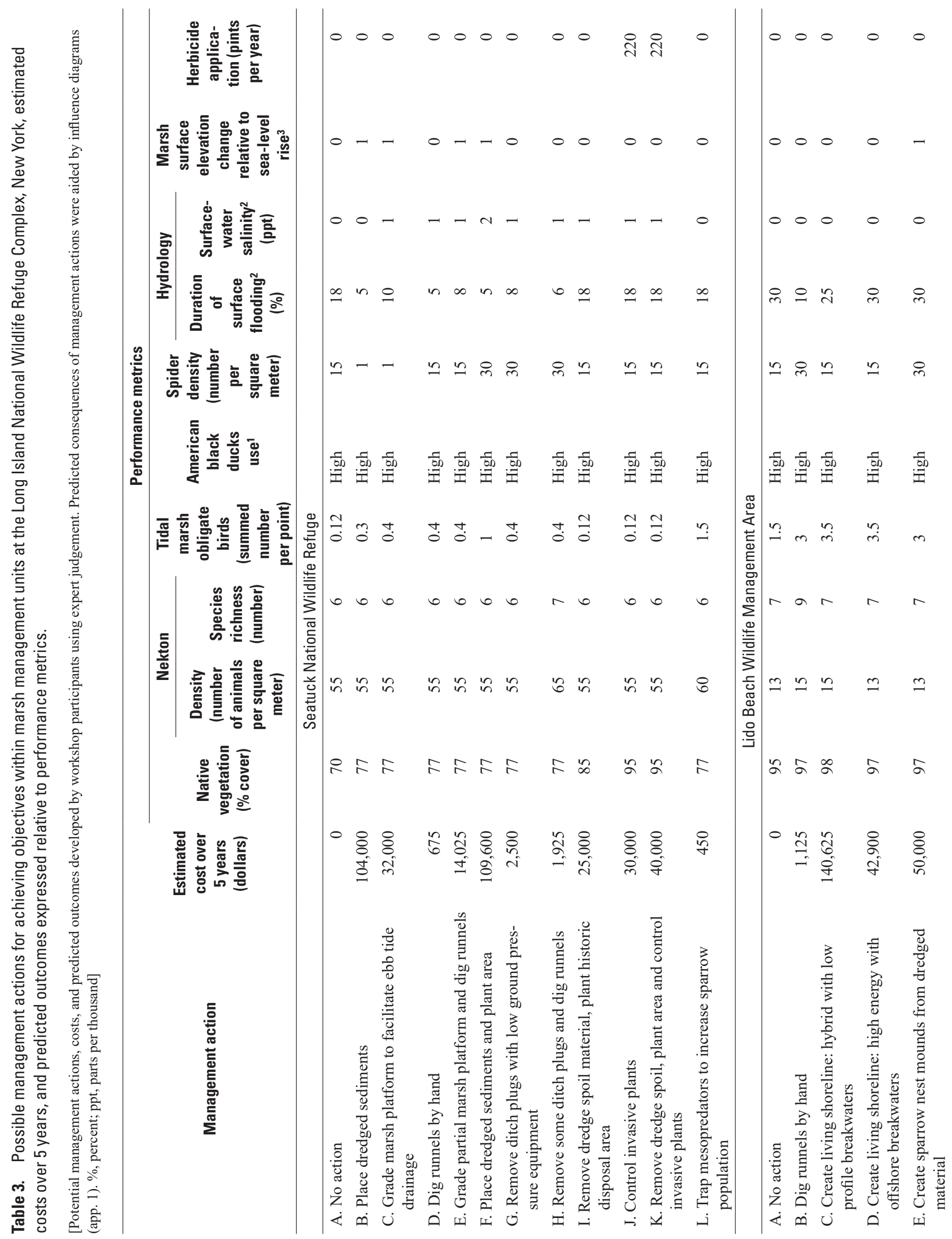


Table $3 \quad 17$
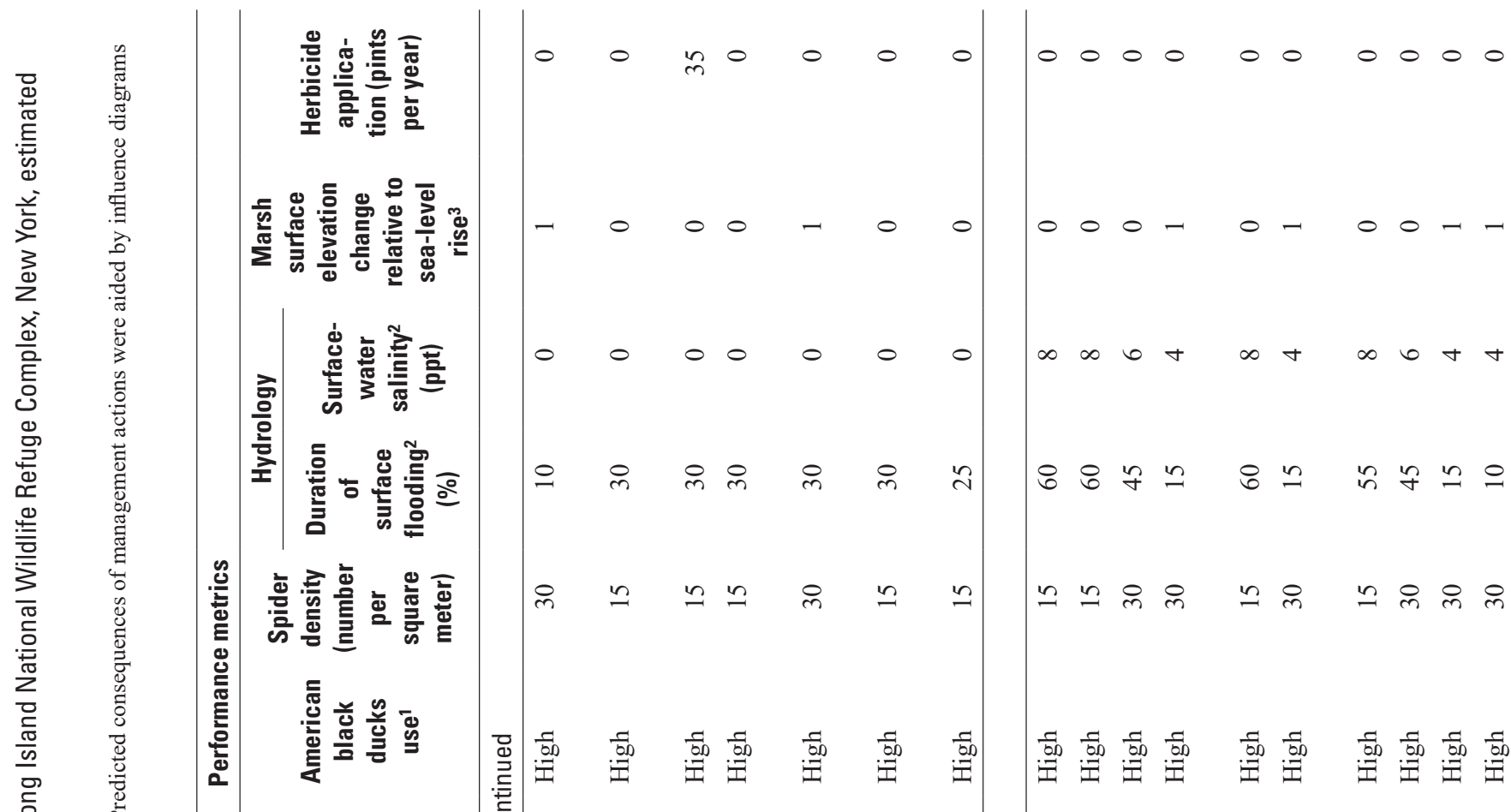

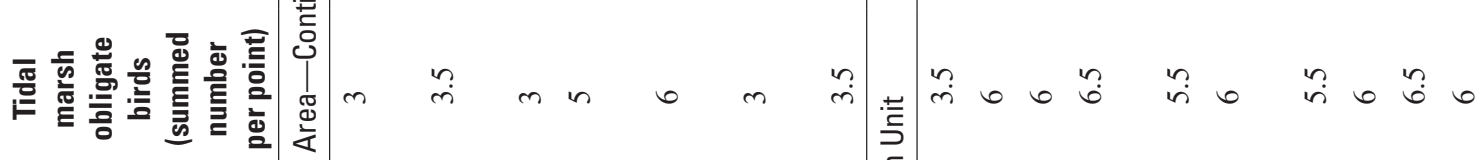

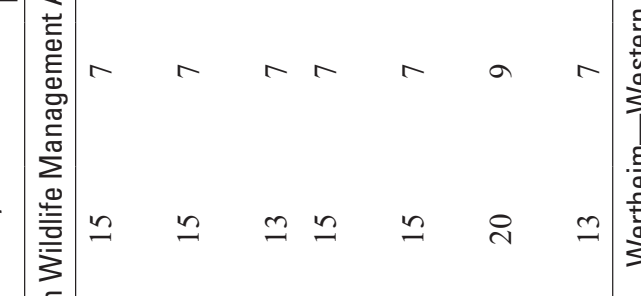

党

売

is 요

离

$\frac{0}{3} \frac{\pi}{0}$

잉ํㅇ

峁

흥

c)

$\frac{\vec{d}}{0}$

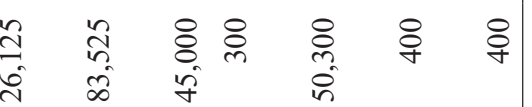

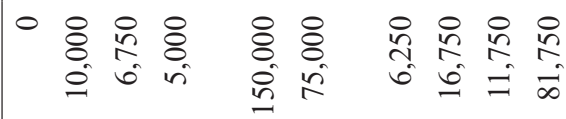
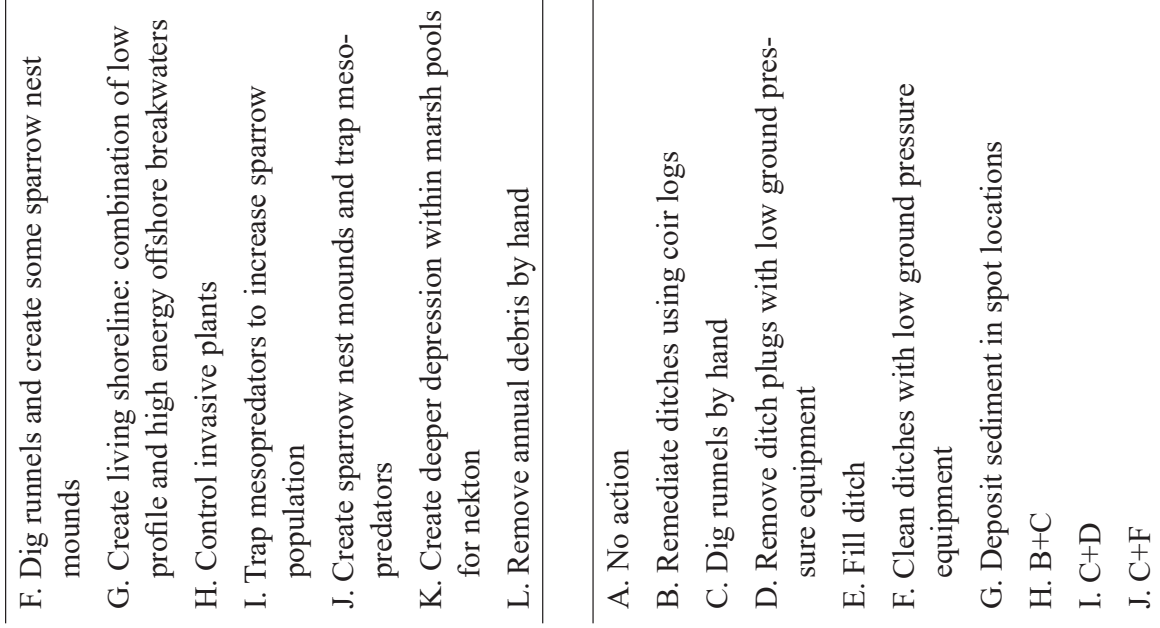

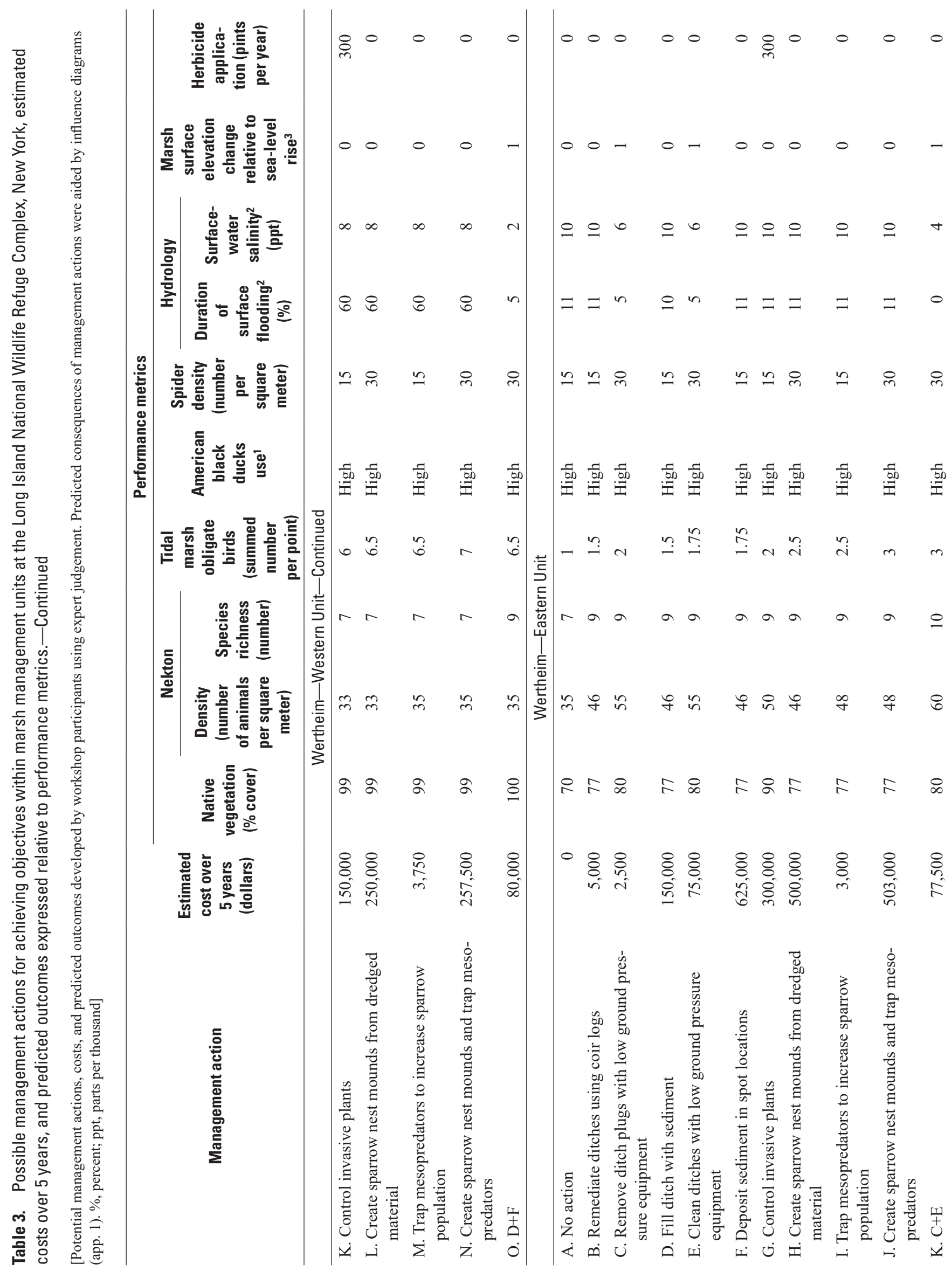

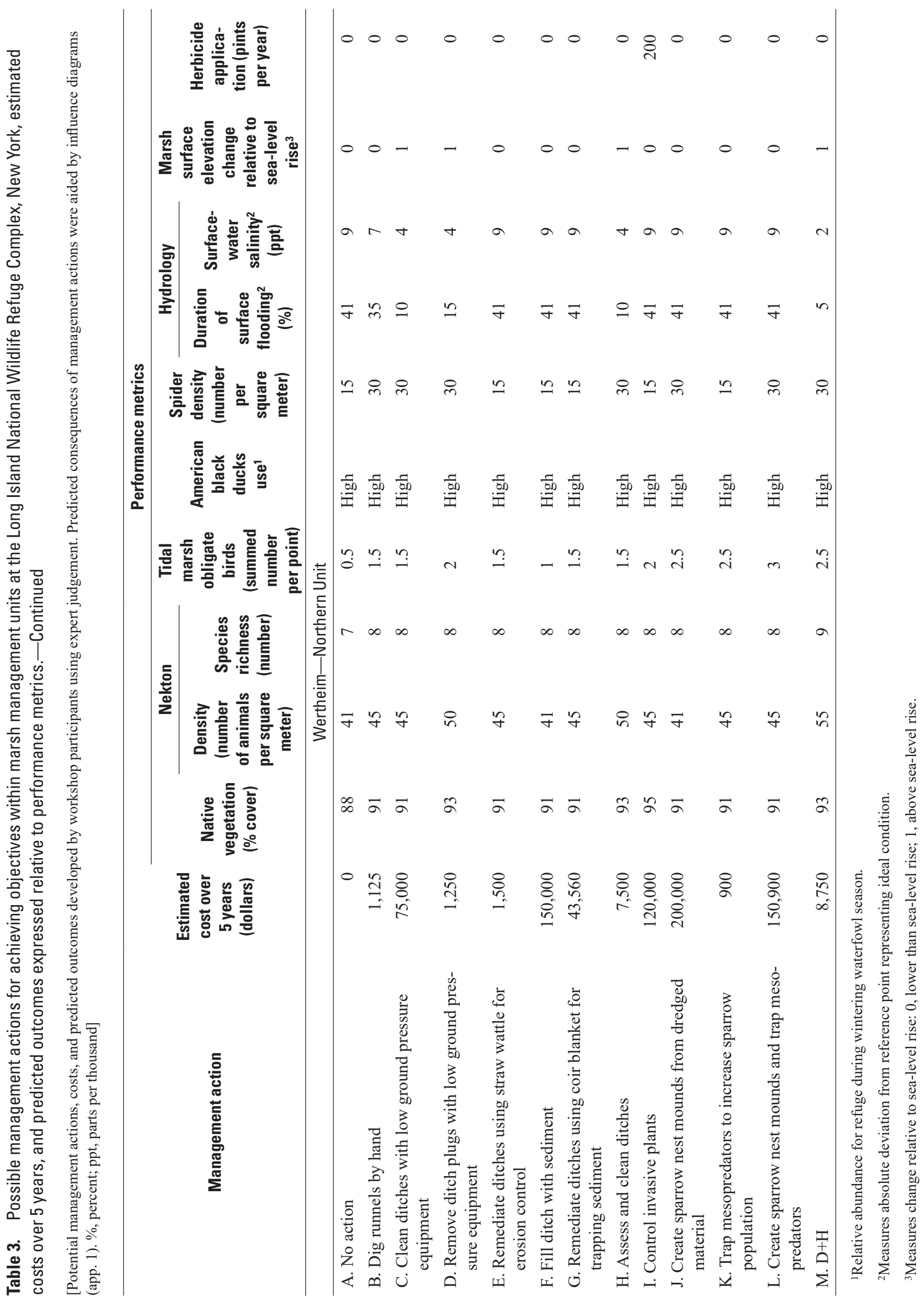

월

.

흥

c

음

志

Eㅎㅇ흥

Фั

들 을

E

क⿺

लू

○ เ

m वे

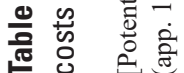




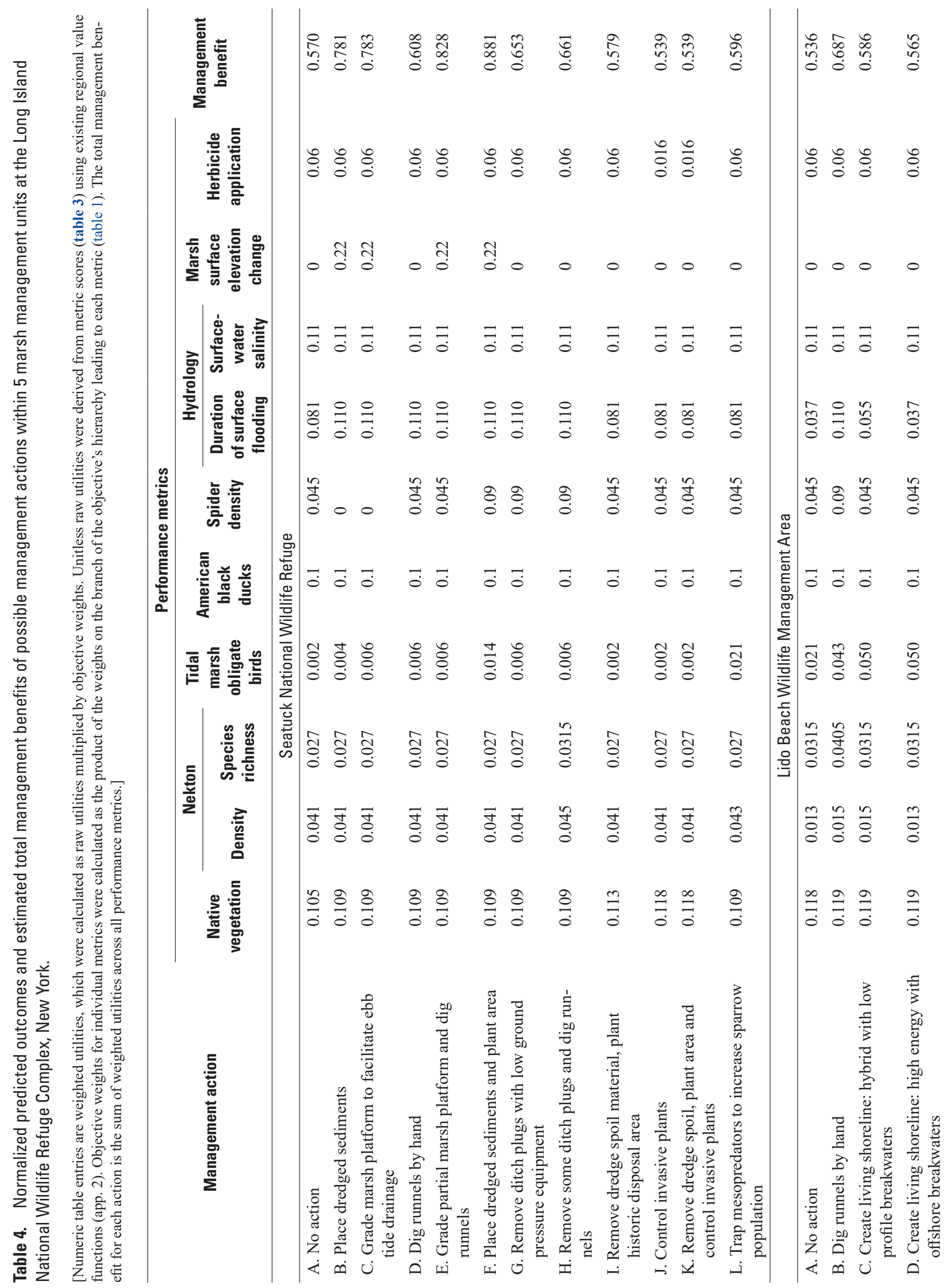




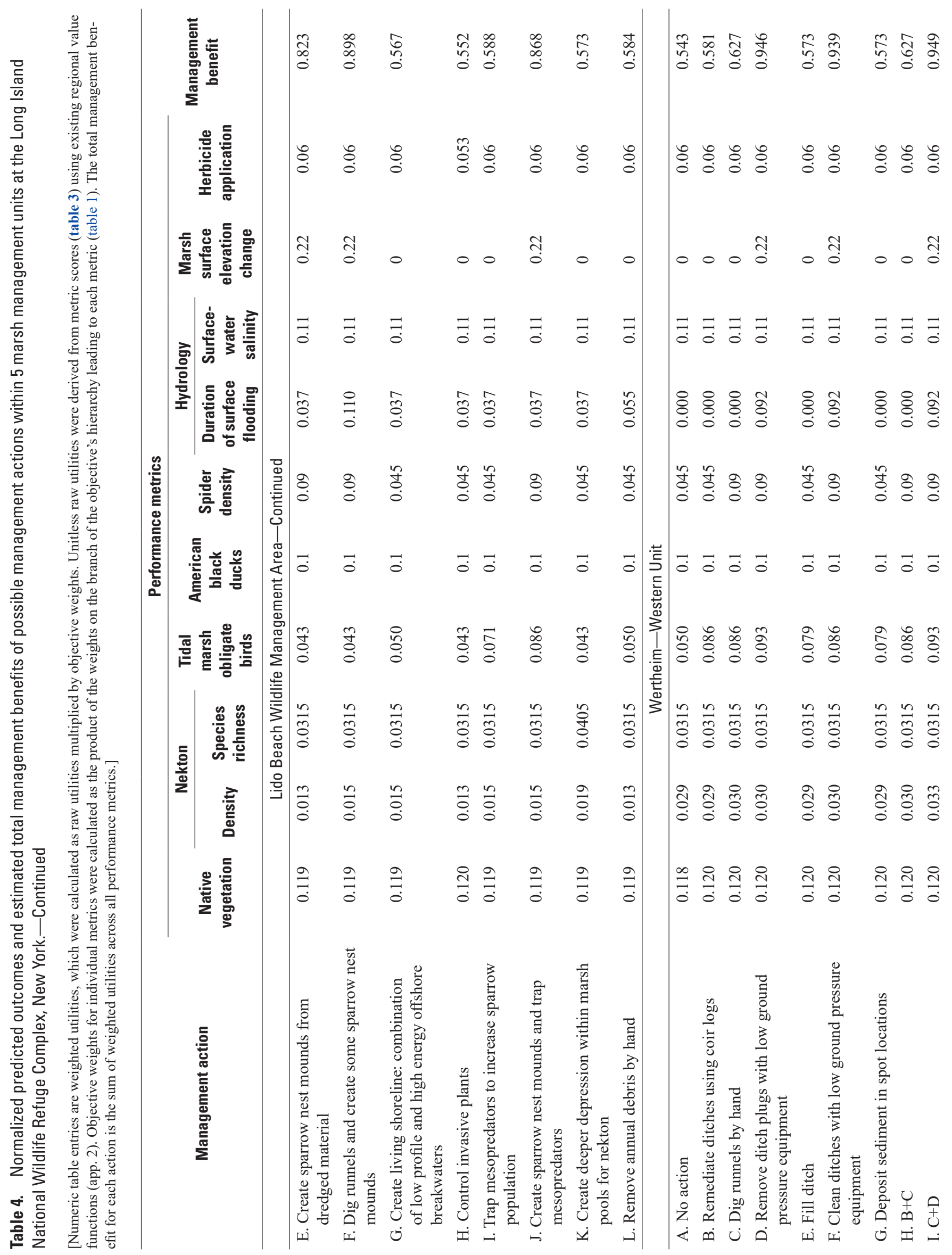




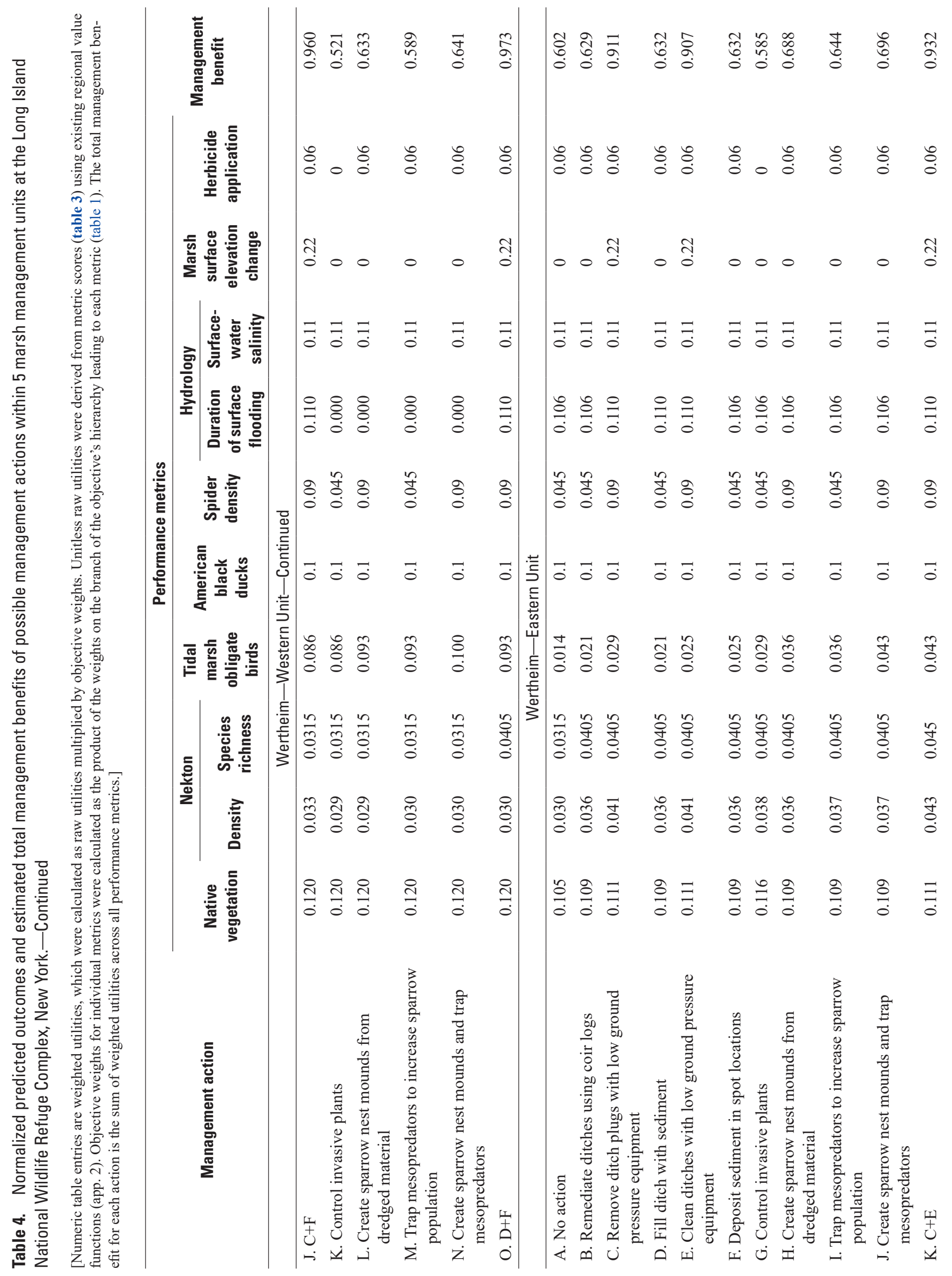




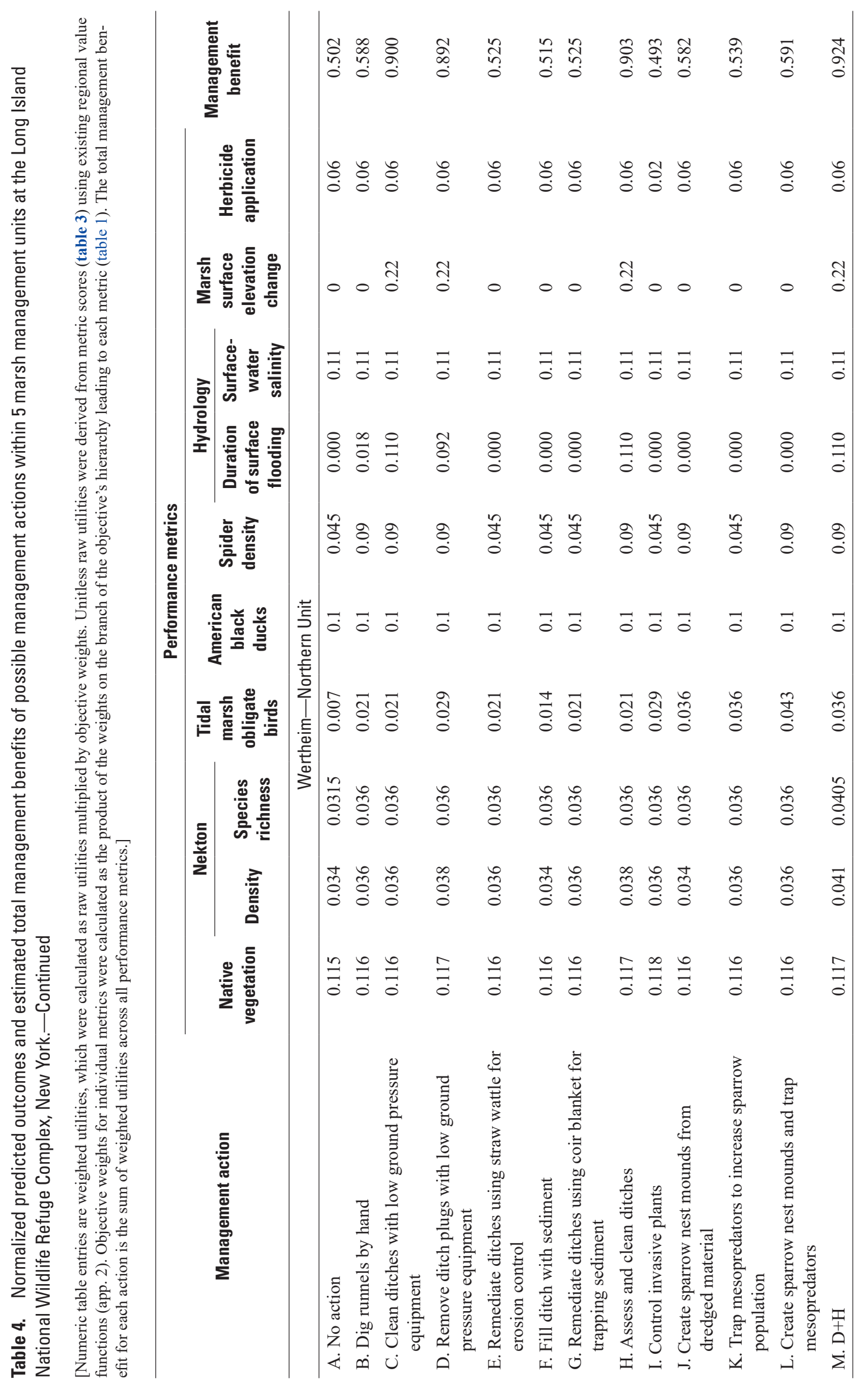




\section{Appendix 1. Regional Influence Diagrams}

The influence diagrams (following the style of prototype diagrams in Neckles and others, 2015) in this appendix (figs. 1.1-1.8) relate possible management strategies to performance metrics. Shapes represent elements of decisions, as follows: rectangles for actions, rectangles with rounded corners for deterministic factors, ovals for stochastic events, and hexagons for consequences expressed as a performance metric.

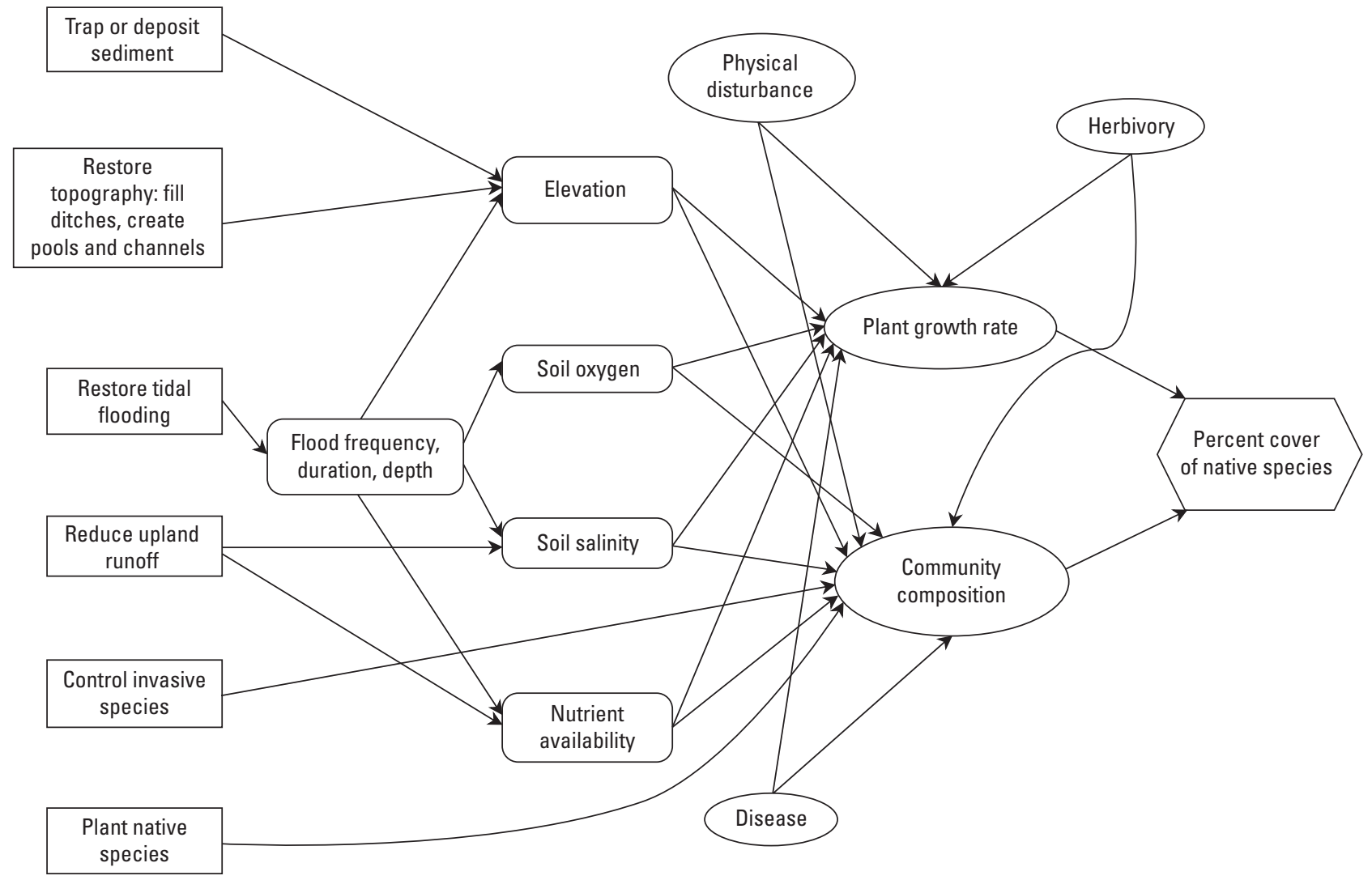

Figure 1.1. Influence diagram used to estimate percent cover of native vegetation in response to implementing certain management actions. 


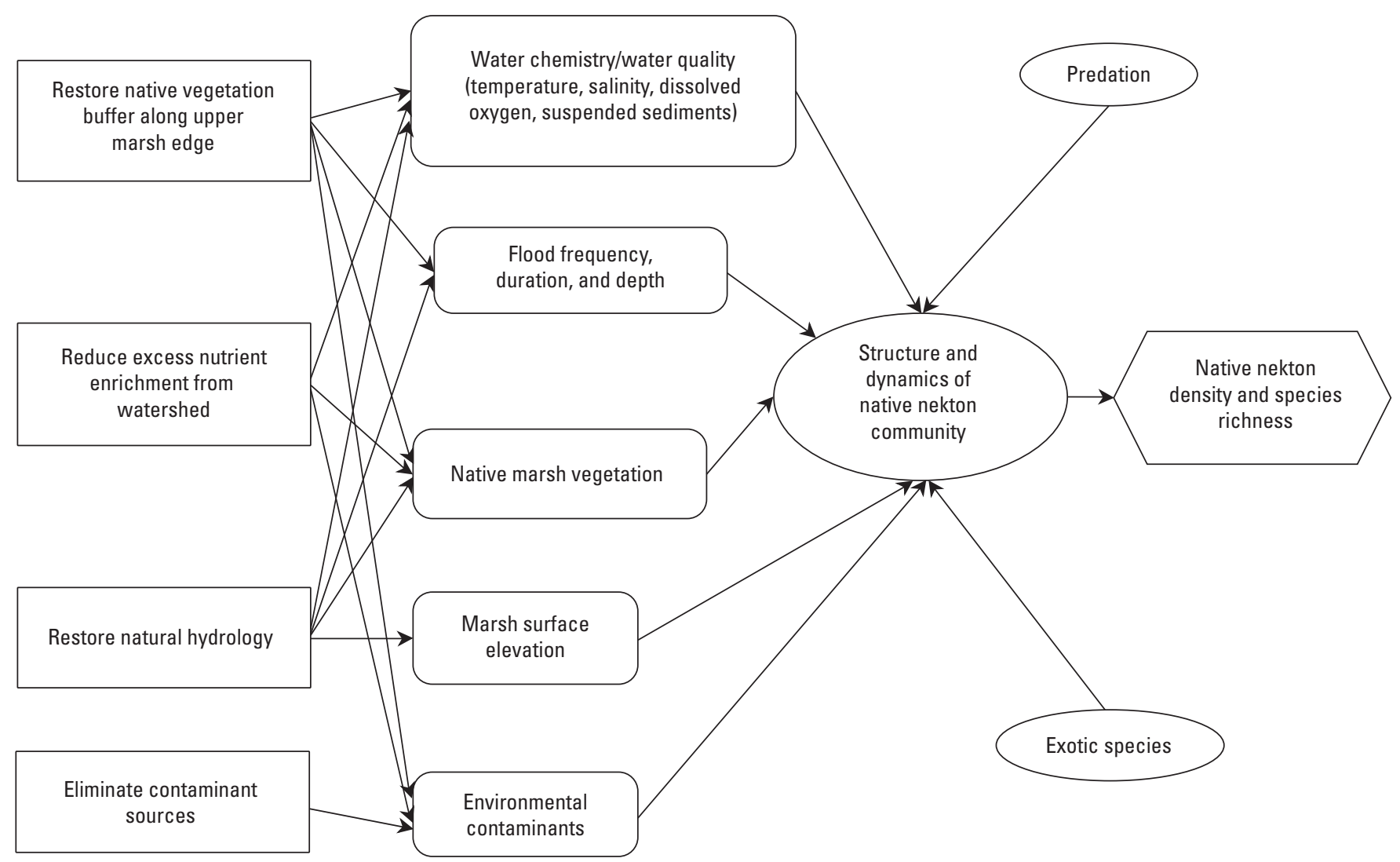

Figure 1.2. Influence diagram used to estimate nekton density and species richness in response to implementing certain management actions. 


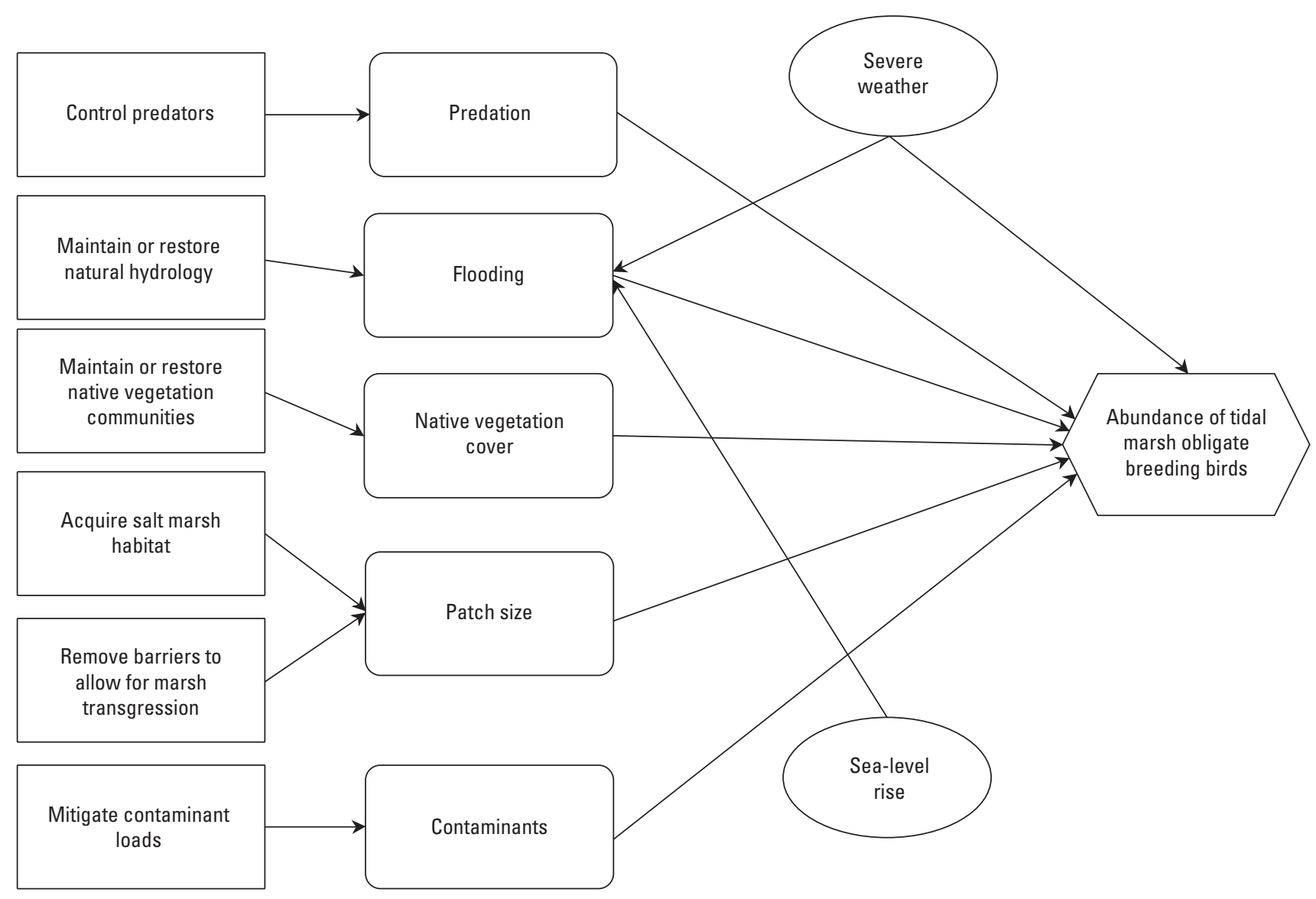

Figure 1.3. Influence diagram used to estimate abundance of tidal marsh obligate breeding birds in response to implementing certain management actions. 


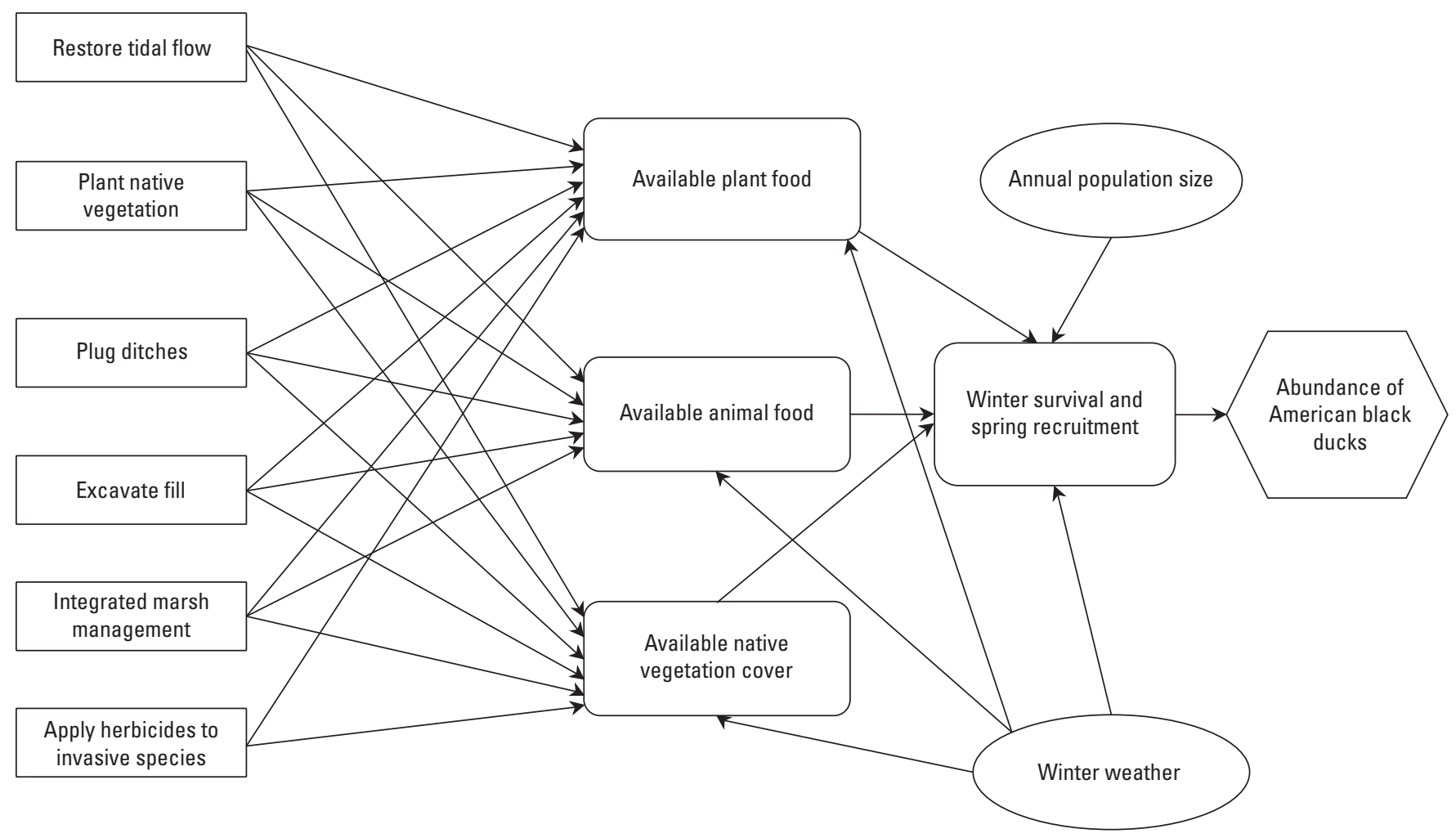

Figure 1.4. Influence diagram used to estimate abundance of American black ducks in winter, as indicator species for nonbreeding wetland birds, in response to implementing certain management actions. 


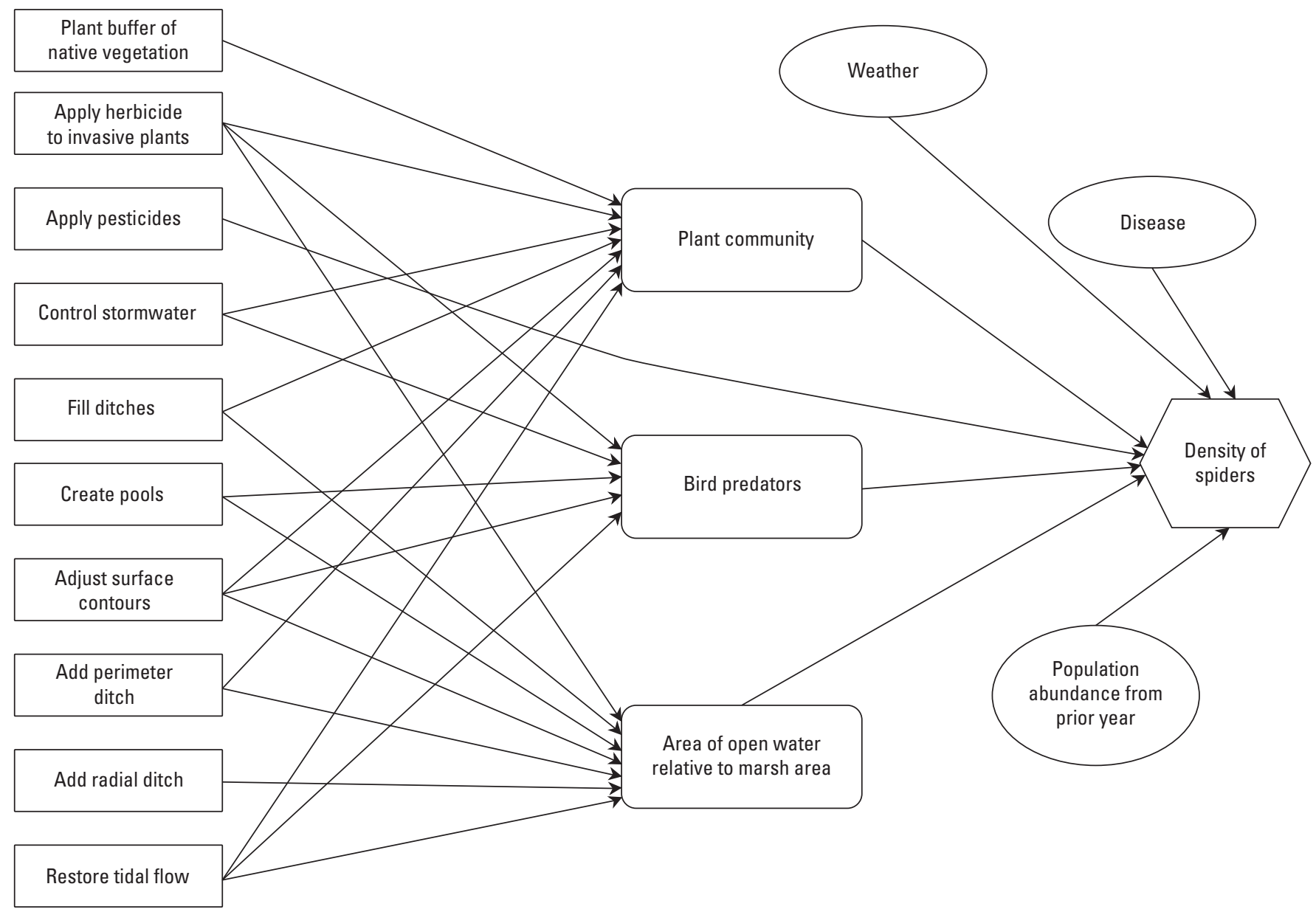

Figure 1.5. Influence diagram used to estimate density of spiders, as indic ator of trophic health, in response to implementing certain management actions. 


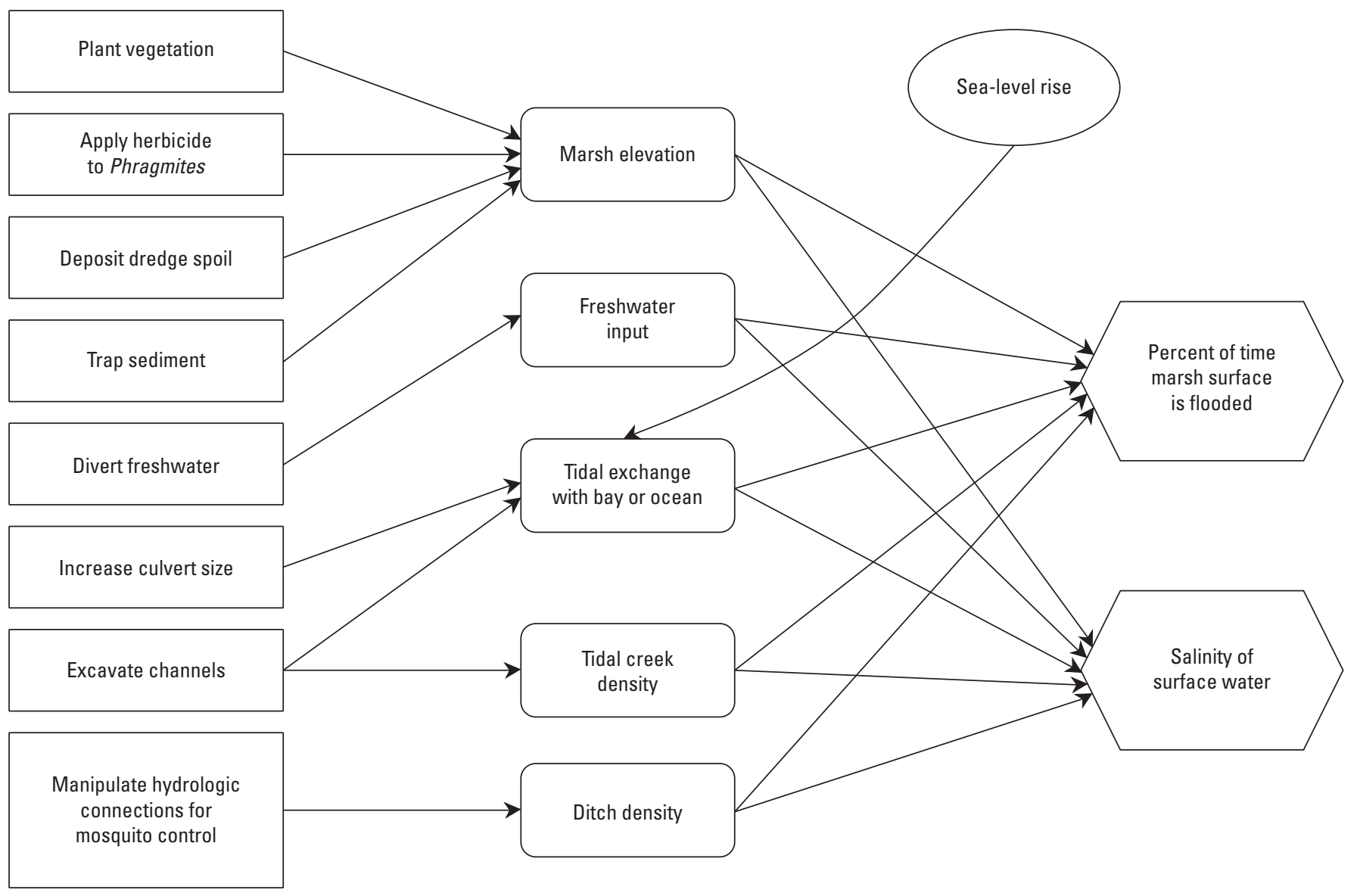

Figure 1.6. Influence diagram used to estimate percent of time marsh surface is flooded and salinity of marsh surface water in response to implementing certain management actions. 


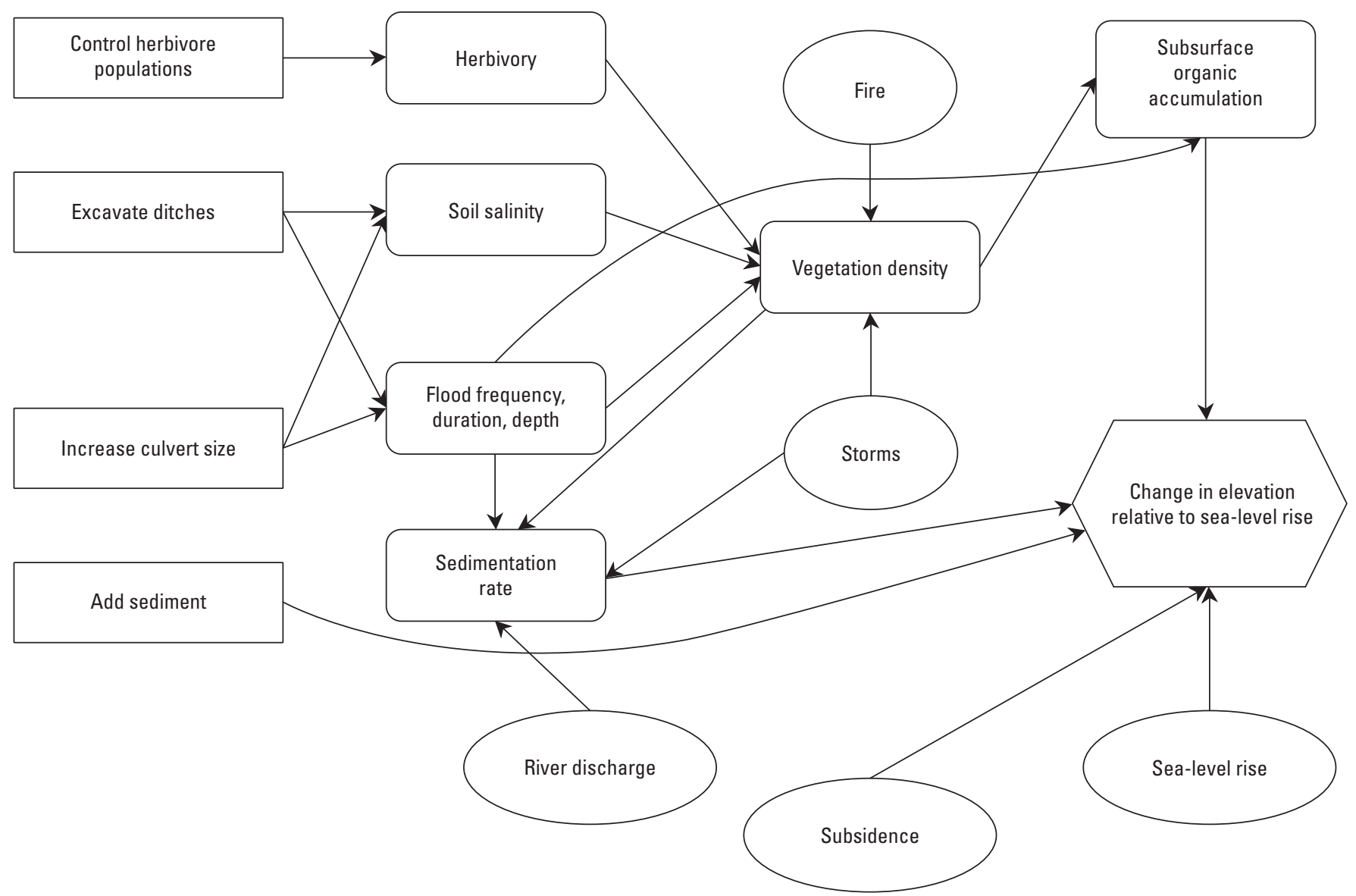

Figure 1.7. Influence diagram used to estimate change in elevation of the marsh surface relative to sea-level rise in response to implementing certain management actions.

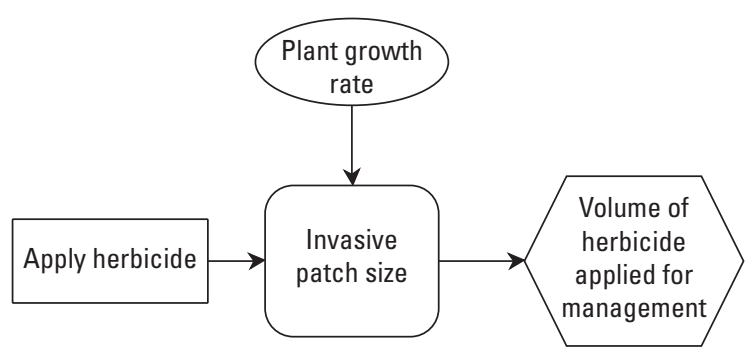

Figure 1.8. Influence diagram used to estimate volume of herbicide that could be applied if a decision was made to use chemical control for removing unwanted vegetation.

\section{Reference Cited}

Neckles, H.A., Lyons, J.E., Guntenspergen, G.R., Shriver, W.G., and Adamowicz, S.C., 2015, Use of structured decision making to identify monitoring variables and management priorities for salt marsh ecosystems: Estuaries and Coasts, v. 38, no. 4, p. 1215-1232. [Also available at https://doi.org/10.1007/s12237-014-9822-5.]. 


\section{Appendix 2. Utility Functions for the Long Island National Wildlife Refuge Complex}

Utilities $[u(x)]$ are derived as monotonically increasing, monotonically decreasing, or step functions over the range of performance metric $x$. In the functions in figures 2.1-2.10, $x$, Low, High, and $\rho$ are expressed in performance metric units; Low and High represent the endpoints of the given metric range for the Long Island National Wildlife Refuge Complex; and $\rho$ represents a shape parameter derived by stakeholder elicitation (Neckles and others, 2015). Break points in step functions were also derived by stakeholder elicitation.

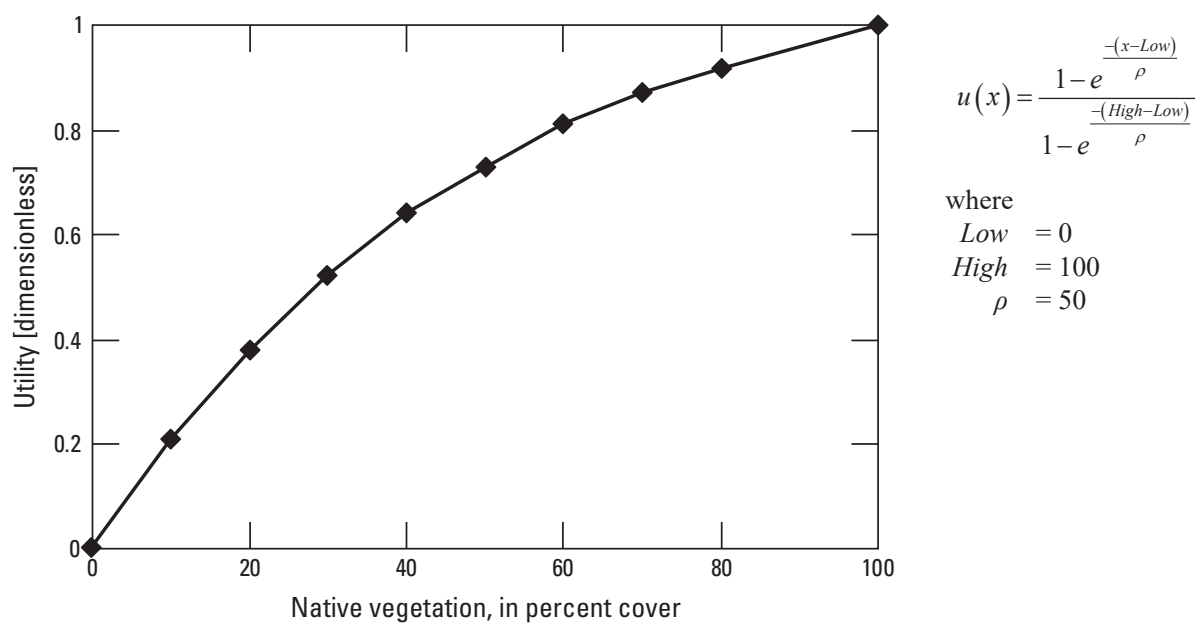

Figure 2.1. Native vegetation at the Long Island National Wildlife Refuge Complex, New York.

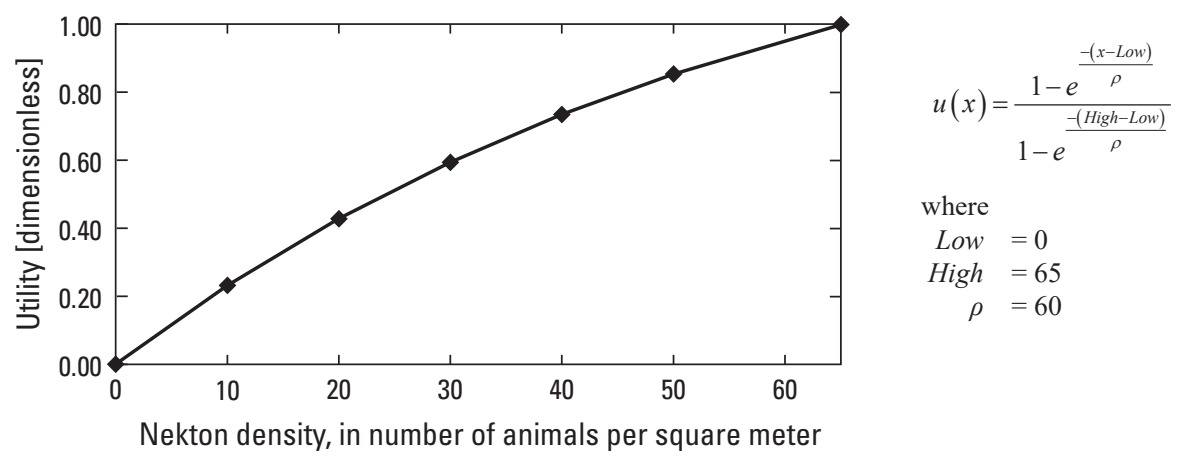

Figure 2.2. Native nekton density at the Long Island National Wildlife Refuge Complex, New York. 


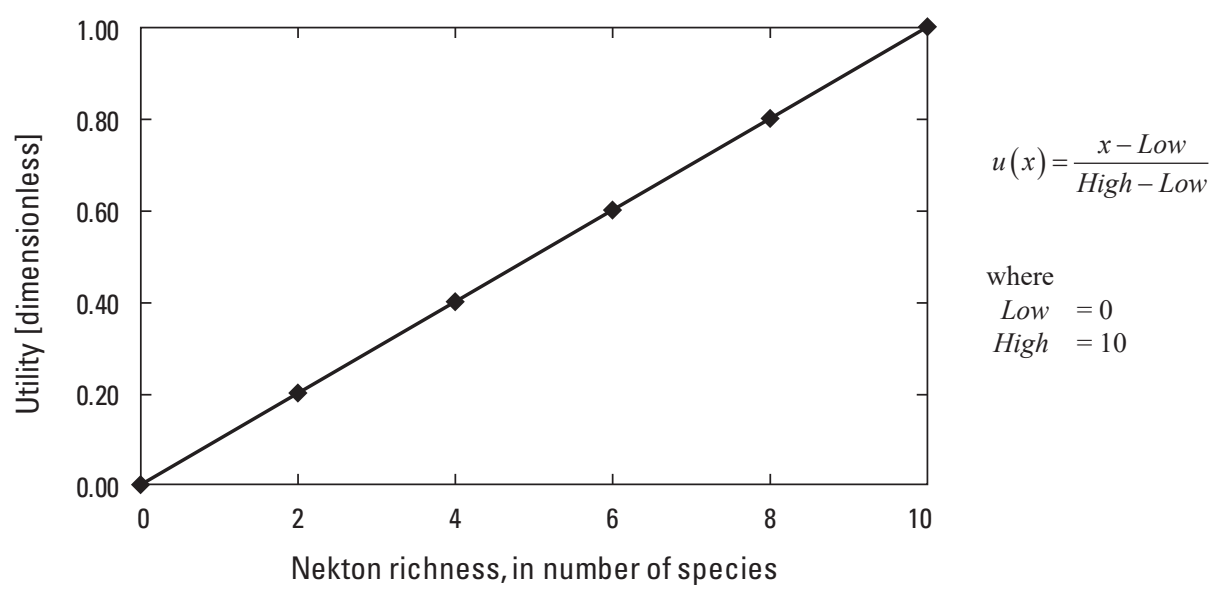

Figure 2.3. Native nekton species richness at the Long Island National Wildlife Refuge Complex, New York.

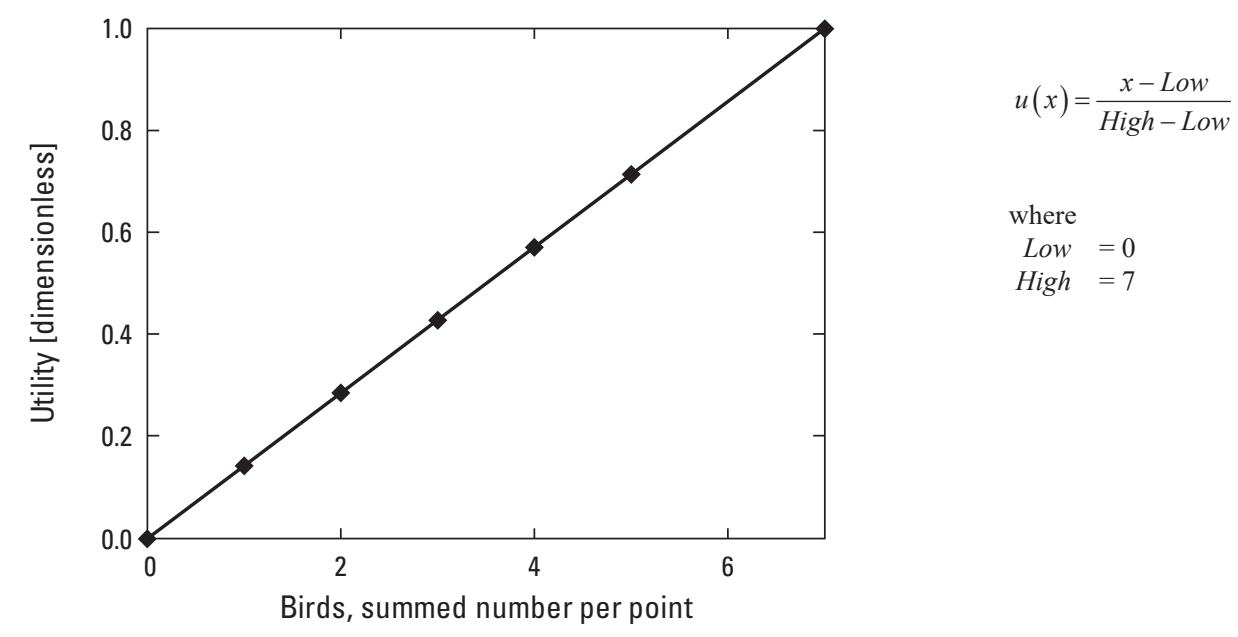

Figure 2.4. Tidal marsh obligate birds at the Long Island National Wildlife Refuge Complex, New York.

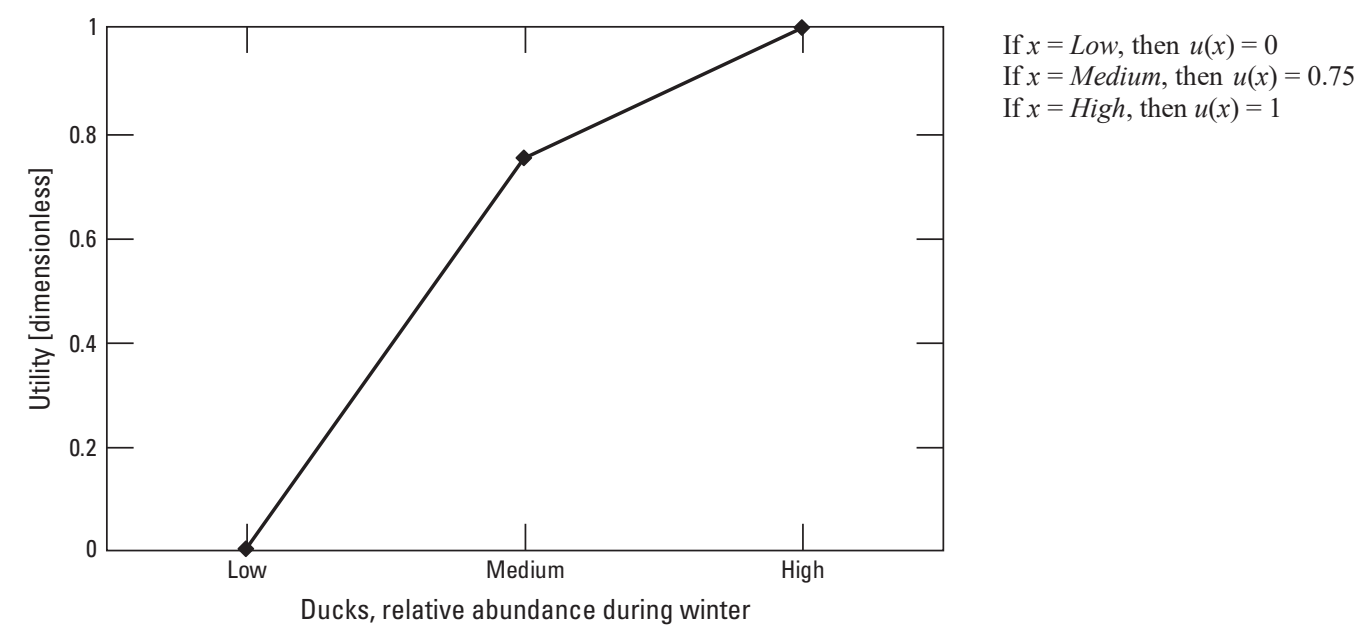

Figure 2.5. American black ducks at the Long Island National Wildlife Refuge Complex, New York. 


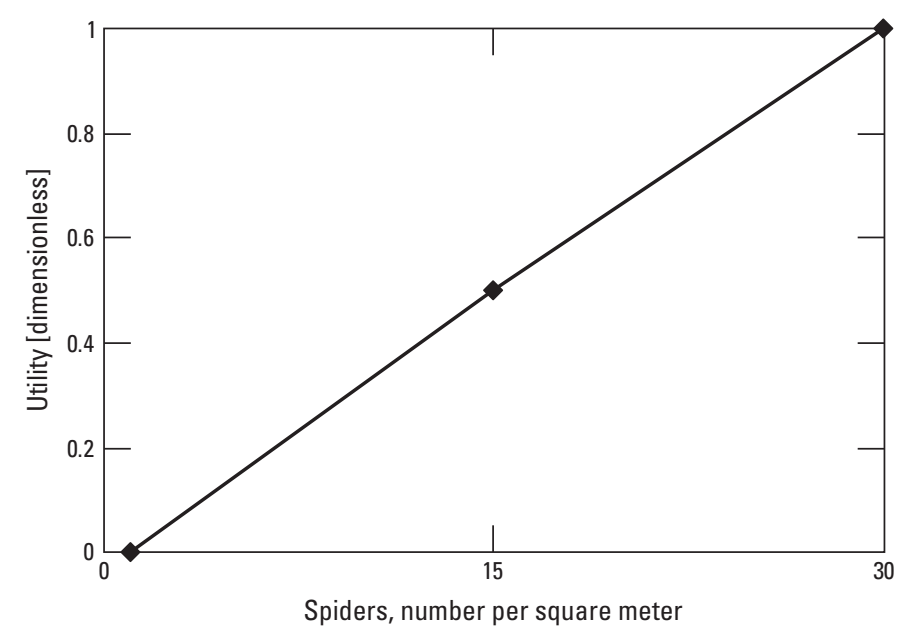

$$
\begin{aligned}
& \text { If } x \leq 15 \text {, then } u(x)=0.5 \times \frac{x-1}{14} \\
& \text { If } x>15 \text {, then } u(x)=0.5+\left(0.5 \times \frac{x-15}{15}\right)
\end{aligned}
$$

Figure 2.6. Marsh spiders at the Long Island National Wildlife Refuge Complex, New York.

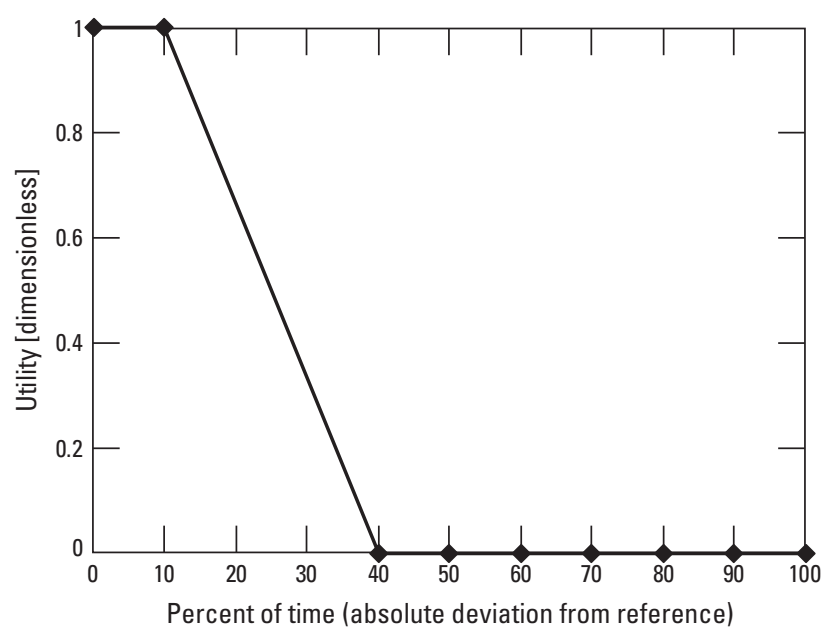

If $x \leq 10$, then $u(x)=1$

If $x \geq 40$, then $u(x)=0$
If $10<x<40$, then $u(x)=1-\frac{x-10}{30}$

Figure 2.7. Duration of surface flooding at the Long Island National Wildlife Refuge Complex, New York.

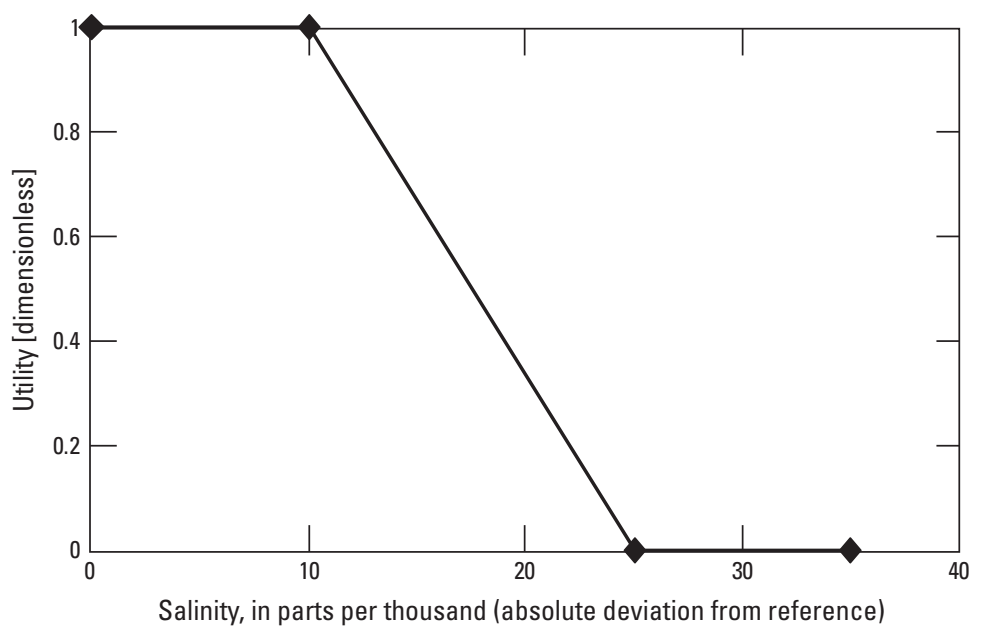

If $x \leq 10$, then $u(x)=1$

If $x \geq 25$, then $u(x)=0$

If $10<x<25$, then $u(x)=1-\frac{x-10}{15}$

Figure 2.8. Salinity of surface water at the Long Island National Wildlife Refuge Complex, New York. 


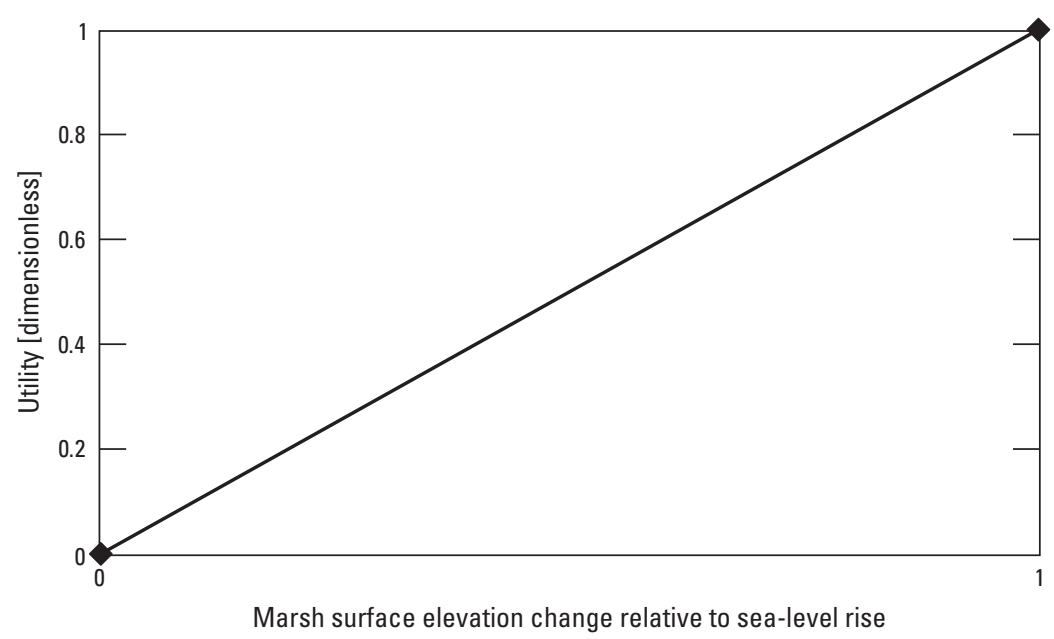

$$
\begin{aligned}
& u(x)=\frac{x-\text { Low }}{\text { High }- \text { Low }} \\
& \text { where } \\
& \qquad \begin{array}{c}
\text { Low } \quad=0 \text {, lower than sea-level rise } \\
\text { High } \quad=1 \text {, above sea-level rise }
\end{array}
\end{aligned}
$$

Figure 2.9. Change in marsh surface elevation relative to sea-level rise at the Long Island National Wildlife Refuge Complex, New York.

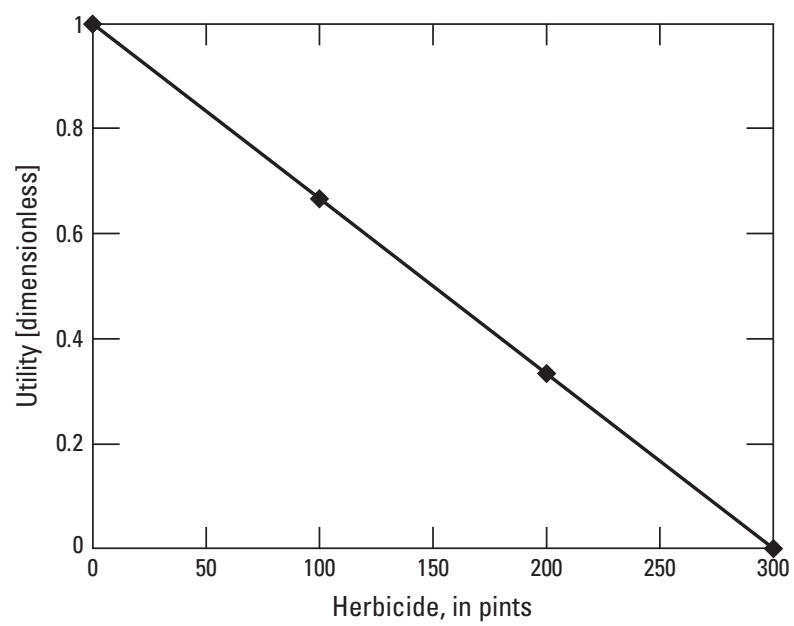

$$
\begin{aligned}
& u(x)=\frac{\text { High }-x}{\text { High }- \text { Low }} \\
& \text { where } \\
& \text { Low } \quad=0 \\
& \text { High }=300
\end{aligned}
$$

Figure 2.10. Application of herbicides at the Long Island National Wildlife Refuge Complex, New York.

\section{Reference Cited}

Neckles, H.A., Lyons, J.E., Guntenspergen, G.R., Shriver, W.G., and Adamowicz, S.C., 2015, Use of structured decision making to identify monitoring variables and management priorities for salt marsh ecosystems: Estuaries and Coasts, v. 38, no. 4, p. 1215-1232. [Also available at https://doi.org/10.1007/s12237-014-9822-5.] 
For more information, contact:

Director, Eastern Ecological Science Center

U.S. Geological Survey

11649 Leetown Road

Kearneysville, WV 25430

or visit our website at

https://www.usgs.gov/centers/eesc

Publishing support provided by the

Pembroke Publishing Service Center 


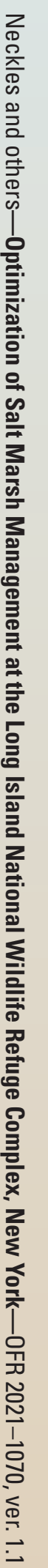

